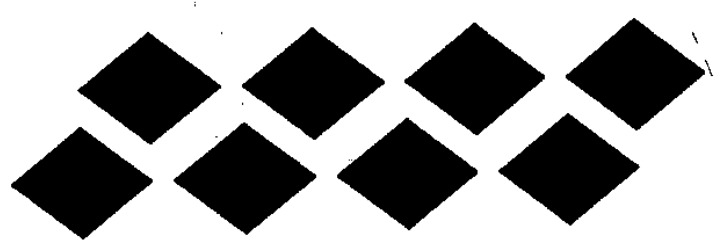

The Quest for Order: A Comparative Study of J. Conrad's Heart of Darkness and W. Golding's Lord of the Flies

\author{
Ahmed Hussein Khalil \\ Qena Faculty of Arts \\ South Valley University.
}




\section{The Quest for Order: A Comparative Study of J. Conrad's Heart of Darkness and W. Golding's Lord of the Flies}

Ahmed Hussein Khalil

In a continually shifting world, whoever can get an orderly icon of anything? Whenever one perceives an image of something, he or she is not expected to hold it for long because other persons come to discredit it by hypothesizing other entirely different perceptions. This world is ipso facto changeable. Even scientific phenomena, known to be immutable, give in to this law of nature. Hence, insofar as our perceptions of this world cannot take immutable forms, they can never be dependable. However, searching for some order in this world had gone into high gear in the distant past and has been holding steady ever since.

Since quests for order or solid facts are idiosyncratic, this world is unsurprisingly represented in different images. Each one's experiences must play an influential role in the images approached. In one sense, everybody looks upon things the way they are experienced by him or her. It turns out to be a really enigmatic issue as such approaches are conceded; their holders are always held up to questioning due to their upsetting longestablished grounds of several historical and scientific facts as well as philosophical and religious conceptions. Observing this, one is enticed to cite a debate on just one example of the late Victorian and modern novelists who have taken the venture of rewriting some aspects of the human history (e.g. imperialism, primitivism, civilization, and man's nature) in an attempt to verify, to the opposite of other scholars, that these aspects are paradigms of anarchy in this world.

It is this paper's main aim to compare Joseph Conrad's Heart of Darkness and William Golding's Lord of the Flies, two 
Dr. Ahmed Hussein Khalil

prominent novels which have been appreciated at large by countless critics but still are debatable; they seek order but fail to find it anywhere in a world ruled by endless chaos and mystery, the reason of which the two writers attribute to man's innate evil. A concept of man as such is indeed very old, as old as Greek mythology, albeit it is viewed by Conrad and Golding from a quite different scope. Golding looks upon evil "as a blind alley," so does Conrad (B. F. Dick 1967: 103). The borderline between light and dark, symbolically good and evil, is intentionally blurred by these authors due to their great influence by certain experiences. If Conrad's witness of the atrocities of the European colonists in Africa haunted him, so did Golding's engagement in the Second World War. The hideousness of such experiences has provoked both writers to think inwardly and come out with an argument that man's heart is the center of darkness in this universe.

There are some other grounds which may validate this comparative study of Conrad (1856-1924) and Golding (19111993), despite the wide gap of time between the two. It is noteworthy that Conrad's Heart of Darkness is repeatedly estimated as a long tale of all times, therefore it is unsurprisingly put 'ahead of them.' Apart form using a new technique, "Conrad addressed issues of the day with such alert adroitness and ambiguity that he anticipated many twentiethcentury preoccupations" (Cedric Watts 2000: 45). Similarly, Lord of the Flies' main focus on morality and man's position in the universe as well as his alienation will never make it an exhausted piece of literature as long as man lives. 1 Dick assures that although the story was criticized by innumerable critics, it "still remains an impressive first novel, and one would be hard pressed to find as good an initial piece of fiction from any of the post-World War II novelists" (98). Both novelists blame their own white civilization for mercilessly exploiting people within and outside the European borders. The two also write simple stories but wrap them with similar sophisticated techniques. 
The Quest for Order: A Comparative Study of J. Conrad's Heart of Darkness and W. Golding's Lord of the Flies

Conrad's novel follows the adventures of its hero Marlow, a steamer for the Belgian Societé Anonyme pour le Commerce du Haut Congo (Limited Company for Trade with the Upper Congo), into the Congo state, symbolically the heart of darkness, in an effort to see how the agent Kurtz was doing his job over there, namely to write a full report on the natives' moral and cultural life for the International Society for the Suppression of Savage Customs and to be in charge of gathering the ivory available in the region. After a long, arduous and risky journey, he returns with the dead body of Kurtz and, much more important, with illumination about the reality of not only the primitive Africans or the white colonists but also of his own self. Following the same journey technique, but with a plane instead of a ship as in Conrad, Golding's Lord of the Flies shows the horrible adventures of a pack of schoolboys marooned, after the crash of their plane in a nuclear war, on an isolated island. At the end of a long and bloody dispute over establishing order in the island community, the surviving children are taken back home on the deck of a ship. Like Marlow, the hero child Ralph learns about the true, ultimately evil, nature of man. The two stories also use paradox as a general technique, with an underlying irony.

From this brief external look at the general frame of the two novels, it may come to light that they are transparent of their writers' ideas, themes and conceptions. However, a deep internal look may expose hidden secrets. Each novel tackles a sort of darkness lying at different levels, which is ab initio signified by their titles. Heart of Darkness "refers not only to the heart of 'darkest Africa' but also to Kurtz's corruption, to benighted London, and to innumerable kinds of darkness and obscurity, physical, moral, and ontological" (Watts: 47). Lord of the Flies points to 'Beelzebub,' a devil defined in both Old and New Testaments to be "most stinking and depraved of all the devils..." (Ramji Lall 1992: 281) Both titles thereby stand as a symbol of the devilish, identifiably dark, side of man's heart, 
which comes to the surface when man, regardless of age, is delivered from the restraints of customs or social laws. As a microcosm of this world, each novel is overshadowed, from the beginning to the end, with endless mystery. More importantly, the structural ingredients of each story are made to work together harmoniously to incarnate such a murky atmosphere within its frame, ironically signifying the civilized world.

As far as setting is concerned, Conrad's story takes place in many different and distant areas, whether in Europe or Africa, which are neatly strung together by the most commonplace journey technique, whereas Golding's sticks to one location, an isolated coral island to the south of Britain. The intricately symbolic embodiment of the setting in the beginning of each story is ominous of more mystery and anarchy to come. Heart of Darkness commences with showing the ship Nellie halting on the Thames in wait for "the turn of the tide" to set out to Africa (1). In the distended horizon "the sea and the sky were welded together without a joint, and in the Iuminous space the tanned sails of the barges drifting up with the tide ... in red clusters of canvas sharply peaked, with gleams of varnished spirits" (1). This image of light, as expounded by the Iuminous sea scene, is made to stand at variance with that of the surrounding land: "The air was dark above Gravesend and farther back still seemed condensed into a mournful gloom, brooding motionless over" Kent, which is ironically called "the biggest, and the greatest, town" not just in England but "on earth"(1). This apparently plain representation of setting is indeed dubious. Deep below the antithesis there seems to lie a sordid irony. The commonplace image of light and darkness, symbolically good (or innocence) and evil, is proposed to be analogous to Europe's appearance and reality: Europe's attractive civilization, as propagated to be the center of light (or civilization) for the whole world, really cloaks an unfathomable evil. This dark reality of the continent is gradually given rise in the novel. Under the pretension of civilization (or 
The Quest for Order: A Comparative Study of J. Conrad's Heart of Darkness and W. Golding's Lord of the Flies

modernization), Belgium, like ancient Rome and Victorian England, is repeatedly shown to exploit the African economy and strip people of their identity. Brian Spittle's contends that Africa was in the 1890 s "the arena... for international political, economic, and occasionally military, conflict." 2 It is thus logical to read that these criminal deeds of colonists are finally doomed to a gloomy darkness that will continually lurk over the skies of their homes. Actually, the image of juxtaposed light and dark is used at large in the novel, but to point to various realities. With every flash of light used to reveal a side of a character, scene or situation is always associated an intense stream of darkness. There is no doubt then that the things contained in the novel are made from the very outset to appear, as they really are, out of order.

The revelation of some other paradigms of color-binary opposition, namely light and darkness, may give more credit to this point. Marlow, the central character and narrator of Conrad's novel, envisions the Belgian capitol Brussels as 'whitewashed sepulchers.' Since the exterior attractive look of the graves contrasts with their interior reality, the rotten or decayed bones of the dead, the imagery here implies that the beautiful façade of the city hides its truly ugly reality. It is on this ground that many critics have claimed that Belgium, like all other early colonists (e.g. France, Portugal, Germany, England, Spain, and Netherlands), had embellished its brutal behavior in Africa with the charm of economic profits for both countries, and, much more importantly, with civilizing the primitive Africans. This notion is sustained by Adena Rosmarin's statement that the whole scene is redolent of the Bible's figuration of the hypocrite, "the man of inner darkness whitewashed by outer manner and conventional deed" (1989: 161). In order to collect all amounts of ivory available in the ironically called 'free' state of Congo, as commanded by the Belgian company, the chief agent Kurtz consumes the energy of the native workers, and kills many of them. Hence, the 
fascinating whiteness of the ivory, analogous to the white façade of the company, conceals behind it the skulls and the ribs as well as the joints of the native laborers. One of the scholars fleers at this nasty reality of the company by wondering: "What if the Company's real objective were wealth derived from a trade in bones?" (The Victorian Web) On the other hand, the African natives should complacently, and indeed ridiculously, content themselves with "the great white lie of the White Man's Burden with its implicit, pseudo-altruism," if they are to be ameliorated, "transformed into white people with black skins" (The Victorian Web). Such ironic discrepancy between the reality and appearance of white civilization is vehemently underlined in the novel, where Marlow pities the miserable condition of a group of the African laborers by saying: "I could see every rib, the joints of their limbs were like knots in a rope; each had an iron collar on his neck, and all were connected together with a chain..." (Heart of Darkness, 20). He hardly believes that these creatures can by any possible means be called "criminals" or "enemies," as propagated by the white colonists (20). If these people's real life is hard, it is hardened more and more by the colonizers: "the outraged law, like the busting shells, had come to them, an insoluble mystery from the sea" Marlow adds (20).

As the novel progresses, the scene shifts from Europe to Africa. Generally, the latter shows itself to be more mysterious than the former, though in a paradoxical way. The attractive appearance of Europe has been already shown to cloak its very dark reality, while the dark look of Africa may conceal its true innocence. Marlow's first glimpse of the Congo River, the coast and people leaves him numbed: everything around him is black, except for the "eyeballs" of some men that show from a distance to be "white" and glistening" (17). The intimidation of the scene makes him unable to assess anything: "the oily and languid sea, the uniform somberness of the coast, seemed to keep me away from the truth of things, within the toil of a mournful and senseless delusion" (17). The only aspect of reality which 
The Quest for Order: A Comparative Study of J. Conrad's Heart of Darkness and W. Golding's Lord of the Flies

divulges some sense to Marlow is the sound of the surf at the coast, which he feels to be "like the speech of a brother" (17). A place as such must not be foretasted to provide any clear image of the Africans, because settings are often known to be formative of their dwellers' outer and inner lives. But Marlow is surprised, as are we, to come to discover that the Africans are not really the way they look. From a distance, he could see some African men paddling a boat at the shore and singing with "faces like grotesque masks..." (17). When he takes a closer look at them, he realizes that they are mild and friendly, a feeling which releases him from the apprehension he has been feeling since the moment of his arrival at the snake-like coast of the Congo. Seeming to breathe again, Marlow said: "They were a great comfort to look at" (17). At this point in the novel Marlow may think, as do we, that he has untangled the threads of the African reality, but he is deceived. Such moment of reality is excitingly temporary, as it soon comes to shift into illusion: "For a time I would feel I belonged still to a world of straightforward facts; but the feeling would not last. Something would turn up to scare it away" (17). The deeper Marlow and his company delve into the Congo River, the more mysterious things turn out to be. They call at many places; all seem unnatural, with "farcical names, where the merry dance of death and trade go on in a still and earthy atmosphere as of an overheated catacomb" (18). The gloom of the scene started to insinuate into their hearts: "in and out of rivers, streams of death and life, whose banks were rotting into mud, whose waters, thickened into slime, invaded the contorted mangroves, which seemed to writhe at us in the extremity of an impotent despair" Marlow admits (18). Over a month of fatigue and stress to reach the mouth of the Congo River these men fail to have "a particularized impression" of anything, and all that they, ironically, could capture was "the general sense of vague and oppressive wonder" that kept over-towering their minds and hearts (18). But this is not astonishing: how can they make sense out of 'a weary' and nightmarish 'pilgrimage?' 
Dr. Ahmed Hussein Khalil

Turning one's attention to setting in Golding's Lord of the Flies, one may detect its indebtedness to certain technical aspects of Conrad. It is worth mentioning that Conrad's intensive use of symbolism and imagery does not only make his style more erudite but also gives his design of the setting more depth. This is however far from claiming that Golding, who won the 1983 Nobel Prize for literature, is not capable of producing an eloquent style. His story's simple and, most often, awkward style may be deliberate; since the setting is for the most part described by the characters, his child characters are not expected to subtly and aesthetically describe what surrounds them, as Conrad's intellectual adults do, otherwise they would never look realistic and convincing. What matters most is that the general frame of setting in Golding's novel is visualized with a smaller amount of symbolism, yet it is no less significant or effective.

Despite variation of setting in the two novels, both works are mainly based on the technique of contradiction between light and darkness or appearance and reality. In the opening chapter of Lord of the Flies, the shore is shown to stand against both the island and the river. Like the false whiteness of the city of Brussels in Heart of Darkness, the luminous shore in Golding's novel conceals behind it the blinding darkness of the island or the forest. This is interestingly elucidated by the image of the palm trees inclining against the beach to blur its light, and by the image of the sun rays struggling to penetrate the thick branches and trunks of the trees (see p.10). Also, the shallowness of the long beach pool is followed by "deep" and "dark green" water (13). Such examples of paradoxical setting may be patterned after Conrad, to whom he is indebted, since Golding employs them as connotative of the despicable mystery, horror and danger lying behind the charming appearance of both the shore and the lagoon, which can be taken as the facade of the island. It is on this basis that the leading children, Ralph 
The Quest for Order: A Comparative Study of J. Conrad's Heart of Darkness and W. Golding's Lord of the Flies

and Jack, become cautious; they "go on an expedition" to find about the island before risking the lives of their fellows whom they leave on the shore (25). They get to the end of the forest and return with the substantial fact that it is an island "and not magicked out of shape or sense," as they have first thought (27). They could see in it "a jumble of the usual squareness, with one great block sitting out in the lagoon. Sea birds were nesting there" (27).

Now the mysterious and fearful looking of the forest changes into a plainly pleasant reality. This unexpected discovery goads the children to scream out: "Wacco!" ... "Whee -aa- oo" as an expression of their exhilaration $(29 ; 30)$. The cheerfulness of the place makes them stop worrying, at least temporarily, about living far away from home, parents and playmates in a deserted island. Every child comes to consciously celebrate the glamour of the island in his own way. For instance, Ralph "stood on his head and fell over"; while laughing, Simon "stroked Ralph's arm shyly," prompting all other children to burst into horselaughing (27). On top of a hill some of the children exult at throwing small rocks down into the sea so as to splash the water up and give the sound of exploding bombs. In another scene, the children are most often shown to enjoy swimming in the lagoon, eating various fruits, singing and dancing. After all, it is hardly surprising to find Ralph, the most intelligent child, in the opening scene of the novel resembling the whole place to his "home counties" (1). Such a portrait of the setting may owe something to the romantic story The Coral Island by Ballantyne. 3

However, this mutable shape of the place is not firm. The paradise-like island is abruptly transmuted into illusion. It no longer remains a safe resort where the children enjoy their life freely, without any parental or school restraints, but rather a house of horror wherein every child is scared to move lonely because it is believed to be inhabited by a beast coming from the 
water and the air. Only Simon, said by many critics to be something of Christ's figure, most often dares to seclude himself in it, but he is scared to death to encounter a slain pig's head on a stick, as a blood offering for attracting the beast, when it comes to speak with him as Lord of the Flies and evil personified. He hurries out to inform his friends about the reality of the beast, but he is not given the chance as all the boys leap in a barbaric way upon him, thinking him to be the beast, and end his life. Henceforth, the island turns into hurly-burly: it becomes difficult to tell if it is still an island or an unknown place, a state of mystery which the children noticed from the very start. Thus searching for an orderly picture of such place seems to have been fruitless all along.

The metamorphosis of characters in the two novels in question may not be just an emblem of the absence of order in the human world, but also of a Darwinian influence; that is, people are the products of their environment. If it is impossible, as displayed so far, to have a steady image of setting (a sea, a forest or a jungle), one is scarcely astonished to face the same problem in attempting to map out the features of the characters in both novels. It may be a deliberate technique of Conrad and Golding to pattern vague settings and types of characters to thicken the darkness of human nature, which is a main theme in their novels. To prove the soundness of such a view dictates the need to assay the characters of each novel separately.

In Heart of Darkness, Marlow starts telling the story of his 'inconclusive experiences' with describing his eerie journey to Belgium to undertake an interview for the post of ship's captain in the Belgian company for trading with ivory in the Congo state. He first comes across clerks, both men and women, who look so intangible that they make him feel "uneasy" and as though he has been "let into some conspiracy" out of which he wishes to get peacefully (12). These human beings do not talk much and look like ghosts. The two old women guarding the 
The Quest for Order: A Comparative Study of J. Conrad's Heart of Darkness and W. Golding's Lorl of the Flies

Company's outside gate and the doctor checking the candidates' health are evident examples. The women are busy with "knitting black wool as for a warm pall" while watching the gate's "door of darkness"; one of them is introducing the incomers "to the unknown, the other scrutinizing the cheery and foolish faces with unconcerned old eyes" (13). The doctor also seems to be out of the common cadre: "He was shabby and careless, with ink-stains on the sleeves of his jacket, and his cravat was large and billowy, under a chin shaped like the toe of an old boot" (13). From the way he examines and questions Marlow, he gives the impression of being insane. While in Africa, Marlow also meets with no less exotic people. Generally, his traveling experiences attest the truth of their having been "somber enough... and pitiful - not extraordinary in any way not very clear either" (6). Such words from Marlow suggest that he is 'perplexed' and 'perplexing' as well. His bewilderment lies in failing to come out of his experiences with clear-cut concepts of all the things he watched, yet he bewilders the reader by maintaining that everything around him looks ordinary. Nevertheless, this implies how difficult, if not impossible, it is for any mind to penetrate the inward reality of things, and thereby any quest for order in this life is anticipated to come to grief.

When Marlow crosses the Congolese borders, he marvels at watching the natives, who view so strange as though they have landed from another planet; each is a set of walking contradictions. The persons dwelling in the forest and on the hills of the central station show to possess no human characteristics; one may not exaggerate to call them animals in shapes of human beings. They walk out naked, yell and yelp like brutes in the wilderness. Such bestiality seems to be a general feature of all the Africans Marlow meets throughout his long journey in the Congo state. No better evidence of this than the ones who have made Marlow "horror-struck," when one of them "rose to his hands and knees, and went off on all-fours towards the river to drink" (23). They- are ape-like men, 
Dr. Ahmed Hussein Khalil

according to Darwin's hereditary theory. To verify this fact, the European colonists in the Congo most often call the natives 'brutes.' At the end of the novel, when Marlow and his crew get to Kurtz's place, we are presented with a much more horrible and mythical scene of the Africans. It is hard for Marlow, and for us as well, to identify these abnormal people who owe much to the cannibals, nether jinni, apparitions, phantoms, and sorcerers - creatures from outside the orbit of our world. Here is how Marlow represents a group of men creeping, like nether jinni, out of their dens in the forest:

Instantly, in the emptiness of the landscape, a cry arose whose shrillness pierced the still air like a sharp arrow flying straight to the very heart of the land; and, as if by enchantment, streams of human beings - of naked human beings - with spears in the hands, with bows, with shields, with wild glances and savage movements, were poured into the clearing by the dark-faced and pensive forest. The bushes shook, the grass swayed for a time (89).

The Russian manager, who is now Marlow's guide in the Congo, appreciates how dangerous these men are. If Marlow does not abandon the smugness of being an august English citizen, he and his men will be gone in a flash. It is no less than a warlike scene comprising unequal fighters; therefore Marlow. has no other choice than to grudgingly resign himself to these cannibal Africans: "I resented bitterly the absurd danger of our situation, as if to be at the mercy of that atrocious phantom had been a dishonoring necessity" (89). But these words conceal a sardonic irony against the atavism of the colonial system, which is behind the way they look; how can phantom-like Africans be so savage as is described by these two white characters? Brian Spittles reaffirms that such the Africans are portrayed in ways which signify ''pain,' 'abandonment,' 'despair,' 'disease,' 
The Quest for Order: A Comparative Study of J. Conrad's Heart of Darkness and W. Golding's Lord of the Flies

'starvation' - the European bequest to the dark continent. Dark in the context because of the evils colonialism has brought" (1992: 84).

The grotesqueness of appearance enshrouding a much more fantastic and cryptic reality is the property of not only the African male characters but also of the females, who are very few and do not appear much in Heart of Darkness. After resting the dying Kurtz aboard the steamer, Marlow watches "a wild and gorgeous apparition of a woman" strolling on the shore against "the gloomy border of the forest" (91). It is unnecessary to quote the detailed delineation of her, which indeed makes her not only opaque but also much more freakishly strange than all the witches represented in English literature; one can briefly state that she is a combination of many eccentric creatures. The truly "bizarre things, charms, gifts of witch-men, that hung about her" prompt Marlow to poke fun at her: "She must have had the value of several elephant tusks upon her" (91). In an identicalness to her men described so far, she is stressed to be "savage and superb, wild-eyed and magnificent..." (91-2). Furthermore, the touches of mystery about this woman culminate in her making unfathomable jerks and gestures which shock Marlow and drown him in a deep stream of darkness: "Suddenly she opened her bare arms and threw them up rigid above her head, as though in an uncontrollable desire to touch the sky, and at the same time the swift shadows darted out on the earth, swept around on the river, gathering the steamer into a shadowy embrace. A formidable silence hung over the scene" (92).

It is quite evident now that the metamorphous state of African men and women is far more than can be fathomed. Much more complicated is the perpetuation of such a state, which is implied in the incomprehensible disappearance of the above mentioned woman: "Once only her eyes gleamed back at us in the dusk of the thickets before she disappeared" Marlow 
Dr. Ahmed Hussein Khalii

says (92).

The only reality of all the African figures discussed so far is that they are black and savage. But, even this 'reality' is doubted because these people are sometimes shown as innocent, powerless and helpless. In one sense, the blackness of their skin contrasts sharply with their 'white' hearts. And the savagery of some of them rises when they are irritated by the alien invaders. If they were really so cruel as thought by the colonists, it would not be so easy to control them by any means. At the beginning of the novel, we are introduced to an idealistic community aboard Marlow's ship, which comprises black and white men together. It is Marlow himself, who first regarded them as weird and wicked, who comes later in the story to confess that they have never done him any harm. This could be viewed by some readers as a kind of dream Conrad wishes to make come true. Even this optimistic view of the scene is enough to break the image of the Africans' as completely dark, with all the connotations of the word; if they were naturally so, neither would Conrad nor anybody else see any good omen in their change. In a ridiculous situation, these barbaric Africans are reduced to helpless slaves. At the project of building a railway across the mountains of the Congo, six black men are glimpsed by Marlow loitering, with legs fettered together with one chain and an iron collar around each one's neck, on a passage. Not only do they look desperate but also subservient to their oppressive masters; while walking forcibly, the slaves keep "balancing small baskets of earth on their heads" (20). In conclusion, the generally antinomic image of the Africans not only dims their reality but also attests to the impossibility of reaching a consistent picture of them, despite Conrad's strenuous quest for it.

The mystery that shrouds Africa and the Africans may be traced by some of us to their peculiarly dark complexion, legendary world, superstitious beliefs and customs, and 
The Quest for Order: A Comparative Study of J. Conrad's Heart of Dakness and W. Golding's Lord of the Flies

primitivism. How about the European figures in the novel? Do their white skin and 'high' civilization make them look straight in the eyes of Conrad as well as the reader? The answer is a definite 'no.' Ironically, all the white characters are most often . implied to be much darker or more mysterious than the Africans.

To begin with the secondary white characters, the Belgian trading agents in the Congo state are ultimately contradictory. They are supposed, according to their company's propaganda, to be missionaries for advancing light in the heart of dark Africa - to illuminate the dark spirits of African natives. It is actually an ideal face for which they deserve the title 'pilgrims' and 'emissaries of light.' But this idealism proves to be a mask these people wear to easily and peacefully get into the borders of an alien country. They are discovered by Spittles to be entirely "alien to civilized behaviour" (1992: 66). And their whole journey does not exhibit any of the common attributes of a holy pilgrimage. Instead of helping people out of the credos mystifying their life and darkening their souls, they thicken their confusion by enslaving them under the threat of highly advanced weapons they have carried with them from Europe. This does not seem to astound Conrad, since what the Belgian colonists do in the Congo is redolent of the early Roman conquerors whom he sketches in the beginning of his novel as outrageous robbers and blind assassins.

The rapacious acts of the European colonists, ironically called 'pilgrims,' are symbolically referred to by the map Marlow sees hung on the wall of his company in Belgium. The European colonies in the world are "marked with all the colours of a rainbow" (11). Here is how Spittles interprets the imperialists' map: "The blue probably represented the French, green Portuguese, orange Dutch, and the purple German. Red signified British..." (1992: 73). Marlow is delighted at seeing "a vast amount" of the map taking the red colour, because this 
Dr. Ahmed Hussein Khalil

denotes "that some real work is done in there" (Heart of Darkness, 11). Here is a sordid irony implied in the connotation of the red colour, and in the reference to it as a 'real' or 'good' work. The writer may want to say that the British colonists' materialistic gains in different parts of the globe are achieved successfully by spilling the blood of other, less powerful, people. The involvement of the British colonists in the Congo is repeatedly underscored in the novel. Spittles emphasizes that setting the novel in the Congo does not mean that "the British are exonerated from responsibility" (1992: 76). Also, this fact has its historical roots: the British colonists fought severely against the Boers, descendants of the Dutch colonies, over the gold discovered in South Africa at the end of the nineteenth century (see Spittles 1992: 70). A bloody history such as this will never be swept out of the World's geography. Conrad's irony is heightened by showing that the colonists drink toasts of exultation over slaughtering the colonized people: "on the East coast, a purple patch, to show where the jolly pioneers of progress drink the jolly lager-beer" Marlow completes describing the map (Heart of Darkness, 11). During his stay in Africa, Marlow could make sure that the Belgian political system holds a good sway over the Africans, a matter which he describes with panegyric but ironic words: there is "a butcher round one corner, a policeman round another" (70). Needless to give further examples of the atrociousness of Conrad's white characters, one can in a nutshell state that the conversion of these characters from pilgrims into butchers is a clear sign of their disordered image; they appear spiritual when they really are materialistic, and civilized when barbaric.

The 'secondary protagonist' Kurtz is another, more striking example of the metamorphous white figures in Heart of Darkness. Kurtz at the beginning of the story is entirely different from the one represented at the end. At first he appears as a first-class agent for the Belgian company, whose rare potential and faithfulness drive others to regard him as an 
The Quest for Order: A Comparative Study of J. Conrad's Heart of Darkness and W. Golding's Lord of the Flies

idealistic type of person. According to the company's reports, he "Sends in as much ivory as all the others put together" (25). To everybody's surprise, this bravest of men dies at the end like a dog: his sick body is left for an army of flies to buzz over it "in a great peace" (25). Such a downfall is indeed mysterious, yet it is justifiable. If there is someone to blame, it is him. He unquestioningly believes the fake economic objectives of his company's existence in Africa, so he blindly exerts all his energy in exploiting all possible means to achieve more than what is required from him. In order to get to his goal, he is sometimes obliged to unregretfully smash the skulls of all those bestial Africans who have disobeyed or obstructed the expansion of his empire. His large appetite for gathering all the tusks available in the Congolese jungles has pushed him to point the highly technological weapons (symbolically, "thunderbolts of that pitiful Jupiter") against the heads of even innocent boys and show no mercy towards the starving African labourers (40). Furthermore, he indulges himself so much in the dark world of the Africans that he becomes unconscious of the dissolution of his own identity into theirs. He thus no longer remains the idealistic person we recognize at the start of the novel; rather, he becomes more cruel than the primitive savages. Only at the end that he becomes aware of the bitter fact that his inhuman behaviour has hurled him into a tenebrous abyss from which he will never be extricated. A little before he dies, his apparitionlike body is handed to Marlow on a stretcher carried by a group of horribly dark men. He looks to Marlow as though were "an animated image of death carved out of old ivory..." (90). Because he is not equipped for such a moment in which all ideals collapse and split into pieces against the hard rock of reality, he cries at his deathbed: "The horror! The horror!" (105). Apart from their wide-ranging interpretation, these words may connote that whoever dares challenge an unknown world, of which Africa is just one example, is predestined to meet such a tragic end. This is why Kurtz points his menacing hand at "a motionless crowd of men made of dark and glittering 
Dr. Ahmed Hussein Khalil

bronze," who have delivered him to Marlow. It is a macabre irony that Kurtz dies aboard the steamboat before getting to Brussels; that is, he dies without clearing the mystery around his own character.

It is noteworthy that Kurtz owes much to the tragic hero because he takes a great part in bringing about his tragic end. Vanity is his own personal flaw. The great amounts of tusk he manages to collect make him believe that there is no "single tusk left either above or below the ground in the whole country" (71). His self-conceit also drives him to think that "everything belonged to him" (34). But his harvest of ivory is, ironically, discovered to be "Mostly fossil," and his possession of everything is no more than "a trifle" (71-2). His consciousness of having everything belong to him must have made him unconscious of the thing he belonged to; he is unable to know "how many powers of darkness claimed him for their own" (72). Marlow and his pilgrims are appalled at his deep involvement in the murky world of Africans - an involvement which has granted him "a high seat amongst the devils of the land" (72). It is ridiculous that Kurtz's present state, for which the Belgian company should be responsible, is regarded by his fellow agents as a symptom of insanity. It is reported that he always liked to wander lonely in the dark forests and live for long days among the strange natives without fear or even any caution; he would "forget himself amongst these people..." one of the reporters assures Marlow (85). In response, Marlow wonders: "Why! he's mad" (85). This sounds like saying that Kurtz should reap what he has sown in Africa.

The infinitely polemic state of Kurtz is another but much more confidential evidence of his metamorphosis. A great many critics have associated him with a number of fictional characters represented in the eighteenth and nineteenth centuries and discovered him to be distinct from all, notwithstanding the versatility of certain aspects of his character to each one. Cedric 
The Quest for Order: A Comparative Study of J. Conrad's Heart of Darkness and W. Golding's Lord of the Flies

Watts (2000: 46) sees that he owes certain traits to the Gothic Fictions' "hero-villains" (e.g. Heathcliff of E. Bronte's Wuthering Heights, whose prototype is John Milton's Satan). Considering imagery in Heart of Darkness, Watts also takes Kurtz "as a modern Faust who has sold his soul for power and gratification." (47) As an imperialist hero, he is indebted to Jonathan Swift's Gulliver's Travels, Voltaire's Candide and Byron's Don Juan. Furthermore, Kurtz's progression into the condensed darkness of the African jungles may reveal his drawing upon Coleridge's Rime of the Ancient Mariner, Chaucer's Canterbury Tales, Homer's Epics, Dante's the Inferno, and Virgil's The Aeneid. Like, for example, the mythical imperialist Aeneas in The Aeneid, whose adventures go beyond this world into the nether, Kurtz digs for the tusks under the ground. 4

The character of Kurtz may be set forth as far more complicated. Although there is no solid evidence of Kurtz's relation to his author, the two are comparable. Kurtz's skeptical attitude to imperialism, mainly brought about by the dichotomy between the Belgian company's pretentious idealism and harsh reality, is most likely inspired by Conrad's same feeling towards the European colonists' exploitation of the Congo state to which he once journeyed as a steamer for a Belgian company trading with ivory in Africa. To Conrad, as mentioned in the preface of his novel under examination, The Congolese state was "the vilest scramble for loot that ever disfigured the history of human conscience..." (xi). 5 The two travel to Africa with idealistic attitudes to European civilization and return with harsh revelations; the only minor difference is that in Conrad's case the revelation drives him to abandon life at sea and the company and reside at home to write novels reflecting his own experiences, while Kurtz's illusion causes his inhumation and horrible death. On the other hand, Norman Sherry suggests that Kurtz is a fictional counterpart of Georges Antoine Klein, 'a 
Dr. Ahmed Hussein Khalil

trader in the Congo,' whom Conrad carried back to London on his ship but died before reaching home (Watts 2000: 48).

A modernist approach to Conrad's novel relates Kurtz to such historical figures as Hitler by claiming that he has got their "charismatic depravity." (Watts 2000: 50) Like them, he believes himself to be the greatest of all human beings. Therefore, he blindly commits horrible crimes. There is no better evidence of this than Marlow's appallment at seeing that the knobs on the posts around the fence of Kurtz's place are human heads instead of pieces of wood. Commenting on the scene, Marlow confesses that the heads, which seem "to sleep at the top[s]" of the posts, do no more than indicate that "Mr. Kurtz lacked restraint in the gratification of his various lusts, that there was something wanting in him..." (Heart of Darkness, $86 ; 87)$. Kurtz's voracious craving for extreme power incites him to think of sweeping away all the Congolese whom he calls "the Brutes" (74). It is scarcely surprising, after all this, to find this character dragged, like his historical counterparts, into corruption and degeneration. David H. Lynn comments on this character's utter destruction by saying: "in the wilderness Kurtz's integrity collapses; only the extremes of appetite and intellect, of savagery and idealism survive" (22).

Kurtz has also become a study case for many psychological inquiries based on the theories of Sigmund Freud, Jung, Northrop Frye, Joseph Campbell and Claude LeviStrauss, and on some naturalists' notions, such as Darwin's evolution theory (see Watts 2000: 50-1). It is concluded that Kurtz's evil is given free reign due to the schism between his 'id,' inclined to satisfying personal needs, and 'ego' or 'super ego,' which fails to hold full sway over the 'id.' To reword it, his striving after achieving an unprecedented progression by all possible means leaves no room for his conscience (or 'super ego') to mediate between the drives of his 'id' and learned values or ideals, therefore he becomes quite blind to his evil deeds. 
The Quest for Order: A Comparative Study of J. Conrad's Heart of Darkness and W. Golding's Lor'l of the Flies

All these sources analyzed above are enough for substantiating the fact that Kurtz's figure is a combination of different persons, which shows how difficult, if not impossible, it is to pass an autonomous judgment on his identity. The mystery about him also leaves its impact on his friend Marlow.

Although Marlow, the chief narrator of Conrad's novel, is claimed to be a straight character, he is opaque. His straightforwardness is perhaps grounded on the notion that he successfully adheres to his own idealism from the beginning to the end of the novel, notwithstanding his discovery of the fakeness of such idealism. Apart from all other characters in the novel, he, as Edward Crankshaw declares, undergoes an "extreme stress" throughout his hazardous experiences on the Congo River and in the jungles on its banks, which are always regarded by Conrad as "devouring force[s]" of nature (1976: xiii). Several times in the novel, he shows himself to be greatly affected by the extreme suffering of the Congolese people under the Belgian system, yet he never relinquishes and insists on getting out of his experience with integrity of the idealism the Belgian company has forced on him. Unlike Kurtz, he refuses to get involved in the impenetrable darkness of Africa, in relation to people's rites or taboos, as he keeps watching it from outside; his 'super ego' thus controls his 'id,' which most often drives him to incline to the harsh reality rather than to the false idealism. However, a reconsideration of this notion may yield the fact that Marlow's character cannot be separated from the mystery and illusion circumscribing in many ways all other characters as well as situations in the novel. The complexity of = this character lies in his perfect holding of many faces, which is bound up with "his very human capacity for good and evil," as hypothesized in the preface of Heart of Darkness (xv).

Marlow's seeming 'faithfulness' is in fact 'unfaithfulness.' This contradiction is mainly. brought about by the disparity 
between his external idealism and inner or real self. In order to keep his vow of secrecy for the Belgian company, he lies to himself and to others around him; he is thus compelled to do something which he very much abhors on the account that it causes him great pain: "It makes me miserable and sick, like biting something rotten would do" he admits (38). There is death in lies, he maintains, yet he chooses to be guilty of that. He watches a great many scenes of corruption and decadence in the Congo, which are not only capable of making him change his ideals towards the colonists but also of sickening him to death, yet he easily lets them go, as he would always "let things slide" (44). Marlow's passivity here stresses that he is dishonest even with himself; otherwise, he would not continue supporting the false ideals of his company, which is behind the horrible decadence of the Africans, or, at least, stand against their unfair oppression on their own land. Furthermore, it makes a criminal out of him, because in this way he indirectly participates in sinning against these impoverished people through letting their destruction go on. But it seems that he intends to keep his personality complexly mysterious by continuing to lie not just to himself but even to others. He refuses to tell the Intended the truth of her fiancé Kurtz; instead of telling her that the last word he uttered was "the horror," he assured her that it was her name (see Thomas C. Moser 1957: 79). Twisting the truth in a way he likes, he believes that his lie is 'white,' in the sense that if the Intended knows the truth she will cry profanity at Kurtz's fake idealism, which is indeed part and parcel of his; thus betraying Kurtz means betraying himself, which is impossible to do. Wilfred S. Dowden supports this notion in thinking that exploring the truth "would have opened the bleakness of his heart to her view; and she would have known the depths to which he had sunk" (1970: 82). To Marlow, it is inhumane to break the heart of a woman who has madly loved a man; the Intended "believed in him more than any one on earth - more than his own mother, more than himself" (Heart of Darkness, 117). Moreover, he was to her a true example of the idealistic 
The Quest for Order: A Comparative Study of J. Conrad's Heart of Darkness and W. Golding's Lord of the Flies

man, whose "goodness shone in every act" and to whom all men "looked up" (116). Finding himself pressured by such woman's unrelenting faith in her fiancé, Marlow comes to soothe her with these hollow and hypocritical words: "His end... was in every way worthy of his life" (117). He strikes two birds with one stone: he helps the Intended have beautiful memories of Kurtz and keeps European idealism, to which he vowed to devote himself, from extinction. Stripping this last reality from its cloak, Marlow finally confesses: "It was ordered I should never betray him [Kurtz]... It was written I should be loyal to the nightmare of my choice" (97). It sounds like a FaustusMephistopheles contract which he dares not violate, because if he does he will surely risk his own life and the whole system of Belgium's imperialism in Africa and other parts of the globe. To Walter F. Wright, Marlow's "goodness and faith were the unrealities" (1966: 159). Once again, Marlow returns at the end of the novel to confirm that he is predetermined to lie: "I remained to dream the nightmare out to the end, and to show my loyalty to Kurtz once more. Destiny. My destiny!" (Heart of Darkness, 106). Marlow also cannot, neither can any one, tell the truth because all human beings are destined to remain out of touch with it. Although man's mind "is capable of anything because everything is in it, all the past as well as the future," it . cannot discern the shapes of these things well, particularly when they are contradictory (52). In a very interesting simile, Marlow returns to philosophize his view of reality: "But there was the fact facing me - the fact dazzling, to be seen, like the foam on the depths of the sea, like a ripple on an unfathomable enigma, a mystery greater" than the gloomy darkness still "on the riverbank, behind the blind whiteness of the fog" (61). A striving as such for an excuse for lying may not be accepted. How can someone, who consciously and voluntarily sells himself to the devil, be easily excused?

Marlow's lies not only leave their impact on him as a principal narrator but also on the structure of the story as a 
whole, therefore they unsurprisingly become the main target of a number of shrewd critical commentaries worthy of consideration. Johanna M. Smith (1989), Peter Hyland (1988), Herbert G. Klein (1988), and Garrett Stewart (1980) are among the modern critics who have laid Marlow's lie to the Intended at the center of their critical appraisals on Heart of Darkness. They concur in one way or another that this lie is more than 'white' or otherwise; it serves the general purport of the novel by furnishing an elucidation of much of its symbolic texture. A retrospective look at, for example, the story's opening, where Brussels and London are respectively represented by the whitened 'sepulcher' and "the brooding gloom" behind "the Iuminous estuary" of the Thames River, may get to the true significance of such strange images of contrast (Heart of Darkness, 1). Juxtaposing the image of whiteness (or light) and darkness (or gloom) against the appearance and reality of these two, ironically called the greatest, cities and associating it with the contradictory image of Marlow as an idealist and a liar may be helpful. The connection here is not forced or even odd, because Marlow is an English citizen and a chief agent of Brussels. Out of this, one can easily understand that the colonists from these two cities are hypocrites, as they pretend to be civilizers and humanitarians, when they really are exploiters and oppressors. The reality of the Belgian may look uglier than the English's, as their appearance, as charming as the whitened sepulchers, does not only ambush their dark or gloomy reality but also their rotten reality. What do graves contain but the rotten bones and skulls of the dead?

There are countless other examples of ironic paradoxes in the novel which seem to rest on Marlow's lies. Due to the limitations of space, one will randomly refer to just a few important examples. Marlow's view of the British colonization, marked by the "vast amount of red" on the map, as a "good" work that will be witnessed by all times may not mean his negation of other colonists but rather his condemnation of the 
The Quest for Order: A Comparative Study of J. Conrad's Heart of Darkness and W. Golding's Lord of the Flies

bloody acts of his own country, acts which will remain a dark spot in its history (11). Also, the whiteness of the African ivory, which turns out at the end to be fossil, is an irony about the African bones with which the Belgian imperialists traded. A vindication of this exists in Marlow's ionic portrait of the white labourers in the Congo as the "faithless pilgrims bewitched inside a rotten fence"; even the air ringing with the 'ivory' stinks, it is "like a whiff from some corpse" (32). Adena Rosmarina presumes that the whiteness of the ivory confuses the reader on the ground that the white colour is capable of producing all other colours of the spectrum; it is not only "offcolor" but also "bespeaks of contamination, a mutual transference between the spheres of morality and vision, between the self one is and the self one seems to be" (1989: 1612). In this context, describing Marlow's lies as white cannot impart his innocence either.

The disparity between Marlow's idealism and reality applies much to the character of the Intended, the dead Kurtz's fiancée. Her illusive idealism is well explained in the contrast between the luminousness of her forehead and the darkness of her room: "But with every word spoken the room was growing darker, and only her forehead, smooth and white, remained illumined by the [in]extinguishable light of belief and love" (Heart of Darkness, 114). Like Marlow, she is not prepared to live without her own idealism, even though it is deceptive and dangerous. Her disinclination to know the harsh and dark truth of her fiancé is not going to make her live happily with the good memories of her fiancé as an exceptionally idealist lover, as Marlow may think, but rather sorrowfully for losing him. More mystery is set about this character in using her not just as an ordinary individual or woman but as a representative example of countless persons. Marion B. Brady sees the light on the Intended's forehead "as a symbol of all those who suffer selfdeception as well as a symbol of all those who practice selfdeception" (1962: 25). To George E. Montage, the Intended 
Dr. Ahmed Hussein Khalil

stands for all European society which abstains from apprehending the rapacious truth of its imperialist system; she "remains as unknowing of the truth as she always has, and remains a part of the foreboding darkness with which the story ends" (1971-2: 97).

It should be quite obvious now that all Conrad's types of characters discussed above are so difficult to understand because they are greatly symbolic and ambivalent. This characterization must be basically influenced by Conrad's view of human beings as amorphous, a look which had probably caused him to painstakingly take the venture of questing for an orderly image of us. Unfortunately, his search gets him nowhere.

The characters of William Golding's Lord of the Flies are no different from those of Conrad in that they have a proclivity to chaos rather than order. The only difference between them is that Golding's characters are children, while Conrad's are adults, a fact which perhaps does not validate the comparison on account that the children are naturally chaotic and become ordered or disciplined only through the adults (e.g. parents or school teachers). But this claim sounds inappropriate since children, especially older ones, are equipped to act maturely. This is to say that Golding's novel is not a romantic story for children, as some may naively think, but rather a wonderful allegory of the evil drives dormant in the nature of all mankind, with no regard for age, colour, nationality or any other boundary. It is because of this that the novel is widely read and highly appreciated by the adult readers around the world, although it is about children. Therefore, any comparison tracing similarities between them and Conrad's adults is not invalid, nor is it without value.

The protagonist Ralph, who is twelve years old, has much of the idealism and illusion of both Conrad's Marlow and Kurtz. 
The Quest for Order: A Comparative Study of J. Conrad's Heart of Darkness and W. Golding's Lord of the Flies

Like Marlow, he is deluded by the false belief that the English civilization always advances its light in the primitive, savage or dark areas outside national borders. At the very outset of Lord of the Flies Ralph commands all the boys to work together in building up an idealistically integrated community of children so as to avoid any kind of danger that may come out of the wild island on which they are forced to live, though temporarily. Agreeing with him, Jack says: "We've got to have rules and obey them. After all, we're not savages. We're English; and the English are best at everything. So we've got to do the right things" (47). As the only owner of the conch, a symbol of power, Ralph strives to be the leader of this community, in a democratic way as all children select and prefer him to his opponent Jack. This implies that he hides a large appetite for authority, which is a common feature of Marlow, behind the pretense of his idealism. Now all the boys comply with his requirements and, accordingly, they live a happy life as though they were in paradise. At this stage, this leading child thinks that the whole world of the island "belongs to" him, repeating the same phrase of Kurtz (31). But, like the latter, he is deceived by the charmingly civilized appearance of the children, which keeps behind it a dark reality.

Ralph's self-deception is also manifested in suppressing his sense of the evil impulses of, especially, the big children (or 'Biguns' as so called in the novel) on the account that he is a stern leader whom all children hold in high regard and affection. Jack's cruel disposition is witnessed by Ralph more than one time, but the latter never pays attention. For instance, in a hunting rehearsal scene, Jack unsheathes his knife and slams "it in a tree trunk" to indicate to his watching fellows that he is not going to have mercy towards the pigs on the island (Lord of the Flies, 34). And in response to Ralph's idea of "sticking a pig," he says: "You cut a pig's throat to let the blood out..." (33). These hints are enough to point to the fact that this boy is obsessed by bloodshed; however Ralph takes it all as 
mere fun. Furthermore, even the progression of the hunting boys' evil drives into a horrible killing of their friends, like Simon's chock at seeing the barbarically dancing hunters in a savagely primitive scene of celebrating the hunting of a pig, does not seem to open Ralph's eyes to the truth. Only when Jack and his tribe kill his friend Piggy and set out to kill him too does he become panicked and take flight into the forest. Now he finds himself facing the horrible truth from which he has been running away; his fear is perhaps far more than that experienced by Kurtz at his delayed discovering of the truth as well. Instead of voicing twice Kurtz's last word 'The horror,' he weeps and declares: "the end of innocence, the darkness of man's heart" at the end of the novel (223). Since the two are prevented (Kurtz by death and Ralph by the fire set to the forest and the death of Simon, the only one who knows the truth of the beast standing for man's evil nature) from transforming the truth, they are in this way not weaned from the mystery spreading over them throughout. Also, Marlow could not transform the truth of Kurtz, a chief representative of the European imperialist system, to the Intended and other European residents. In fact, all of us (writers, characters and readers) appear to be destined to keep groping for an unattainable order in this mythical world we live in. There is no longer a reason why these fictional characters, standing for us, should not look the way they do, disfigured or vague.

Jack Merridew, Golding's secondary protagonist, is also sketched in ways that may not help us pass a plain judgment upon his figure. Only the adjective 'mercurial' fits to describe him. Unlike all characters discussed so far, he is like a chameleon, well known for having the potential of changing the colour of its skin and motion in a rapid way. We are informed at the beginning of the novel that he was at school a striking example of the idealistic boy. He was known as a wonderful singer of church psalms; thereby he won the choristers' head title. At first, he works with Ralph in building up the huts, in 
The Quest for Order: A Comparative Study of J. Conrad's Heart of Darkness and W. Golding's Lord of the Flies

exploring the nature of the place, and in keeping the fire signal burning on the mountaintop. Further, he is greatly interested in hunting pigs for providing his fellows with meat. All of a sudden, he disagrees with Ralph on the matter of watching the fire signal; consequently, he becomes indifferent to what Ralph asks him to do and, more dangerously, he abets all the big boys, except for Piggy and Simon, against him. All his concern now is with hunting pigs and performing primitive dancing rituals, of which the mystical Simon is a victim. Jack becomes not only a savage, but the leader of the tribe of savages. His hostility to Piggy and Ralph causes him to kill the former with the hands of Roger, one of his advocates, and make the latter flee into the forest to hide himself. Much more horrible is his setting the whole forest on fire to smoke Ralph out of it to easily kill him. But, fortunately, a British naval officer comes at the right time to spare his life.

The perfect metamorphism of Jack is well explained in camouflaging his human identity. In order to easily hunt the pigs he smears his face with red and white clay and with charcoal. His face looks weird and funny to the children, therefore he goes to the lagoon to have a look at its reflection; he is astonished because he no more looks "at himself but at an awesome stranger" (Lord of the Flies, 69). However, this new look makes him feel glad: "He spilt the water and leapt to his feet, laughing excitedly" (69). This disguise of face is perfected by Jack's creeping among the bushes and upon the trunks of the trees, exactly like "moths on a tree trunk," to stab the first pig coming into view (68). After a long time of failure, he manages to kill a pig, so he dances and shouts: "Kill the pig. Cut her throat. Spill her blood" (65). But such change of identity does not only serve Jack's apparent objective of providing the children with enough meat, but also attests to his conversion into animalism. He no longer possesses any of the human senses or spiritual qualities which may prevent him from spilling the blood of even his friends. More interestingly, this change of Jack 
and his supporters into primitive savages is also indicated in their performing certain famous rituals of primitivism. In more than one scene, these boys are observed to walk naked, with painted faces, black caps on their heads and spear-like sticks in hands; and in celebrating a hunting or doing a mock-hunt, they dance in circles and chant out barbarously, as repeatedly occurs in, for example, chapter four. They are reminiscent of the early wild Africans or 'red Indians,' as described in history or anthropology. Apart from its being a mocking of English literature's 'noble savagery,' as some critics suggest, this transmission of human beings into beasts is most likely meant to lay a great emphasis on the darkness of their hearts.

Contrary to all the other characters, Simon's mystery or disorder is not determined by his paradoxical acts, but by some new aspects. Unlike all the boys, he is everything but immoral, an idealism that is going to be entirely different from all sorts of idealism attributed to the characters discussed above. At school, he has been one of Jack's choir team, but on the island he devotes himself to the service of Ralph, to whom he is very much indebted, and other boys. From the beginning to the end of his life, he never changes. With this surface view, some readers may think they have a clear image of this boy, but this turns out to be an illusion when these readers come to test such an image against his mysterious disappearance in the forest most of the time as well as his hallucinated speech with the Lord of the Flies. The opposite of all the boys', his attitude to life is mostly philosophical and religious. He is not obsessed, as they are, by the existence of the beast on the island, strongly believing that the beast, a symbol of evil, deeply resides within every man's heart. Besides providing the little boys with the fruits they cannot reach on tall trees, he most often stays "at a secluded spot in perfect solitude in order to hold a communion with the objects of nature" (Lall 1992: 27). Because of his quietness and deep meditation on nature, many critical sources regard him as "a saintly, Christ-like figure in the novel" (Lall: 28). A view as 
The Quest for Order: A Comparative Study of J. Conrad's Heart of Darkness and W. Golding's Lord of the Flies

such may not sound accurate because the Christ or any other holy figure is never mentioned in any religion to have had hallucinations about our realities; rather, some of the mystery in this universe is revealed to us through the prophets, who are God's messengers. We never read in the novel that the truth of the beast is explored to Simon by any of the angels, but rather by an imagined conversation with the head of a pig that is killed and pierced with a stick, which he takes as Lord of the Flies. "Fancy thinking the Beast was something you could hunt and kill! ... I'm part of you" the head tells Simon and warns him to leave away before it can "get waxy" and destroy him (Lord of the Flies, 158-9). Thus Simon's opaqueness exists in his profound spirituality which is not explored to us either by other characters in the novel or by the author's interfering commentaries. Only Simon's seclusion in a part of the island dwelled by butterflies that motivates the reader to look for a symbolic connection; butterflies are a symbol of 'soul,' as psyche in Greek means 'butterfly' (Robert J. White 1964: 163). The author may imply that neither secular persons nor spiritual ones, represented by Simon, have consistent traits, which is greatly ironic.

Golding's other characters, especially the little boys (or the 'Littluns' as so-called), have much of the metamorphosis of the minor characters in Heart of Darkness. In the first place, some of these boys are named and several others are given just the generic title 'The Littluns'; Conrad's minor white characters are likewise named 'The Pilgrims,' while the females, African and European, are denied names. The only difference between the two titles is that the former is an informal word used to refer to just the boys who are below six years old, while the latter is a general religious title for those persons who make pilgrimages to certain holy places, which is employed for an ironic purpose. In the second place, both groups of characters are, regardless of age, self-interested. Like the accountant and the manager in Heart of Darkness, these boys do not worry about the atrocities 
of the big boys around them, but are terribly shocked by the thick darkness of the forest and their separation from home and family, which is a natural feeling of any boys in their same age and situation. Both groups also seem satisfied, especially after becoming accustomed to the new life on the island, with what goes on around them. On this ground, 'The Littluns' may not be regarded as different from the adult pilgrims in being inhumane. They are most often watched to play, swim and eat the reachable fruits, when the big ones are disputing and killing each other: "They ate most of the day, picking fruit where they could reach it and not particular about ripeness and quality" (Lord of the Flies, 64). The animalism in these boys is displayed in their being unable to discern the good food from the bad, therefore they suffer "stomach-aches and a sort of chronic diarrhea," and in their habit of eating and sleeping (64). They sometimes "cried for their mothers..." but "seldom bothered with the biguns" (64). Much more important, these boys also resemble the pilgrims in their being yes-men: "They obeyed the summons of the conch" which Ralph holds as a symbol of authority (64).

It should be quite conspicuous by now that Conrad and Golding's quest for orderly forms of humans does not succeed, as indicated in our deciphering of their various types of characters. This same problem is also encountered in the examination of the themes and ideas tackled by the two authors, which means that they systematically move towards achieving their intended goal behind their novels, namely to prove that any quest for an order of the world we live in is futile.

Both Heart of Darkness and Lord of the Flies can be literally deciphered as journey novels. Nevertheless, each novel is arranged in certain symbolical ways to serve as an inquiry into man's nature. Unlike ordinary journeys, known to have clear beginnings and ends, this kind of journey has no destination. This is however not astonishing, because journeying 
The Quest for Order: A Comparative Study of J. Conrad's Heart of Darkness and W. Golding's Lord of the Flies

into darkness inevitably results in nothing but darkness. It is impossible to aspire to any discoveries or unequivocal facts from such a journey. But this is not the only theme; there are other social, cultural, political, religious and psychological ones which are no less equivocal due to their paradoxical nature. Cedric Watts discovers about eight paradoxical ideas in Conrad's Heart of Darkness, most of which, surprisingly, apply to Lord of the Flies, such as: barbaric civilization, remediable and irremediable society, redeemed and irredeemable imperialism, brotherhood and racism, communication and isolation, morality and immorality, consciousness and unconsciousness, and soul and soulless (47). All these ideas should be considered, at least briefly, to show the impossibility of reaching an autonomous image of each one. Since all these contrasting ideas are images closely bound with man, they thereby can attest to the disordered nature of man, which is the premise of this study.

Watts sees civilization as "both a hypocritical veneer and a valuable achievement to be vigilantly guarded" (2000: 47). How much does this apply to each of the two novels under question? Conrad's Heart of Darkness elaborates, as shown so far, on the disparity between the gorgeous appearance and harshly exploitive reality of the European civilization, represented by the Belgian company for ivory in the Congo state. The latter masks its capitalization on the African economy with the veneer of modernizing African places and people. Like all naïve people who strongly believe the false propaganda of civilization, Charlie Marlow's aunt tries to convince him that the Belgian company is founded in Africa for "weaning those ignorant millions from their horrid ways..." (Heart of Darkness, 15). On the contrary, Marlow knows the truth that "the Company was run for profit" (15). In order to justify their presence there, the Belgian administrators cut roads and railways across the rocky mountains with the pretension of facilitating the natives' moving to the bumpy areas; the natives are easily deceived as they give them a helping hand. In fact, 
Dr. Ahmed Hussein Khalil

this project, along with others, is intended for assisting their prospect for ivory. The result is the defilement of nature and the destruction of the natives. Once again, the entire Congo is sensed by Marlow to be redolent of "the merry dance of death and trade" that keeps going "in a still and earthy atmosphere as of an overheated catacomb" (18). Such a real sense of 'death in life' is intensified by Marlow's delving into the Congolese forests, where he feels as if he were stepping "into the gloomy circle of some Inferno" (22). The African laborers are described at work to be no more than "black shadows of disease and starvation, lying confusedly in the greenish gloom" (22). On the other side, the inhumane company is ironically made to gloat over watching the natives suffer and die horribly. Thus civilization shifts from being a noble mission for modernization into a real work of barbarism and degeneration, the reason for which Watts, depending upon Nordau, relates to "the influence of people who were morally degenerate..." (2000: 46; see also pp. 14-15; 132-4). Conrad's portrait of Kurtz is, Watts adds, mainly based on Nordau's "account of the 'highly gifted degenerate', the charismatic yet depraved genius" (46). Kurtz's vicious crimes equal him with the Nazist Hitler. As a morally degenerate leader, he utilizes European high technologies for destroying the African society, instead of using them for changing it for the better, as he is supposed to do. Out of all this, one can conclude that civilization is really anything but an ordered issue. This image is an ironic parody of Kipling's ideal of the British Empire "as a positive force that imposes a pattern of order on chaos..." (Shamsul Islam 1975: 48-9).

Similarly, Golding's assault on civilization may even be more severe. From the beginning of Lord of the Flies, our attention is drawn to civilization's moral corruption and physical destruction. Here we are not put face to face with the machineguns or warships of Kurtz, but with jets in a nuclear war. The British government shows itself to be idealistically humane in trying to spare the lives of its children by evacuating 
The Quest for Order: A Comparative Study of J. Conrad's Heart of Darkness and W. Golding's Lord of the Flies

them with airplanes in areas remote from the battlefield at home, when it drives the adults to sacrifice their lives for their country's triumph. No better example to cite here than that of the paratrooper who is horribly hung over the trees and whom some of the boys take for the beast. The good side of civilization is represented in inventing highly progressive means of transportation and, much more important, in illuminating dark minds. But such means of progress are most always misused, when they are used for the destruction of the environment and people. Without Piggy's illumination about using his own glasses, a symbol of science and civilization, to kindle fire on the mountaintop as a signal for the passing ships, the boys would
not have been rescued. Nor would they have eaten meat, because they needed fire for grilling the hunted pigs. On the other side, such advantages of civilization are turned by the morally degenerate Jack, who owes much to the character of Kurtz, into disadvantages. To choke his adversary Ralph out of the forest to murder him, Jack sets the whole island on fire. In this way, he uses fire, a symbol of civilization, to demolish the natural environment and kill his friends. Many of the little children are expected to be strangled to death. Far more important, if the survivors had not been rescued at the end, how were they going to live in an entirely burnt place, without food or protection from bad weather? The barbarism of civilization is also explained by Golding in the uncivilized behavior of the supposedly civilized tribe of the hunters. Like Kurtz, Jack orders Roger, a chief boy in his tribe, to kill all the boys who refuse to carry out his orders and who are faithful to Ralph. He kills Piggy with a rock, which he throws from a hilltop onto his head; the whole tribes of the hunters take part in strangling Simon to death in a barbaric dance at a mock-hunt. To underscore their conversion to savage primitive individuals, these civilized English boys change their physical appearance into black Africans and red Indians, as shown so far. Whether in the case of Kurtz or that of the boys, there seems to be no clear lines of demarcation between civilization and savagery, a 
conclusion which underscores the fiasco of any attempts to reach a firmly fixed image of civilization. 6 The infinite chaos of such a civilization may be signaled in the return of the boys to their homeland to restart their life under the umbrella of this same civilization.

All the social forms introduced by Conrad and Golding are shown to be flawed, being remediable and irremediable. In other words, they protect people from corruption, yet they themselves are corruptive. Both European and African peoples appreciate the role their political regimes play in developing their ways of living, yet they condemn them for getting them involved in degenerating issues. These regimes' hunger for money and power drive them to commit horrible crimes against their peoples and others, crimes which they conceal behind their pretension of developing and civilizing humanity altogether. More horrible is that peoples are mostly kept out of touch with the ugly reality of these regimes. They are really deceptive systems, which serve the prosperity of only the elite in any community. An example of this is the atrocities of the Belgian company in the Congo state, which ends the lives of countless natives and reduces the rest to starving animals. On the other hand, the African regime is no less corrupt, as it proves to be fragile and subservient from the beginning to the end of Conrad's novel: it passively accepts all the crimes of the foreign settlers against its people without protest. Golding's island community of the English boys is likewise implied, particularly at the beginning of Lord of the Flies, to oppose that of the English adults. Unlike their adults, the boys appear first to be idealistic in many ways, a feature which does not exist in the mother country, dominated by all kinds of turbulence and corruption. On the island there are no atom bombs, noise, or any restrictions. Enjoying a happy and free life, Maurice does not receive "chastisement for filling a younger eye," named Percival, "with sand" at playing together (65). Here, there is "no parent to let fall a heavy hand" on Maurice for his "wrong 
The Quest for Order: A Comparative Study of J. Conrad's Heart of Darkness and W. Golding's Lord of the Flies

doing" (65). Briefly, the island is, comparatively, much safer and far more comforting. Most surprising is the conformity of this young English community with Conrad's adult European community in terms of their own cultural smugness: they feel proud of belonging to a highly civilized nation. Jack mentions: "We're English; and the English are best at everything" (47).

Like any humane authors, Conrad and Golding are taken by the predicament of humanity brought about by racism and the absence of brotherhood. They unavailingly attempt to create idealistic communities, where all individuals love each other and live together peacefully. To them, brotherhood becomes an ignis fatuus, impossible to attain. The conflict between the European colonizers and the colonized Africans in Conrad's novel, and the nuclear war in Europe as well as the division of the English boys in Golding's novel, all implicate the failure of the writers to reach a solution to this problem. But this is hardly surprising, because the writers themselves participate in complicating the problem when they, consciously or unconsciously, reveal their own racism in a great deal of their writing. Apart from the racism of the imperialists in general, referred to so far, it has been argued that Conrad's representation of Africa largely stems from the writer's bias to his race. 7 This claim has inspired many twentieth-century critics from both Europe and Africa to launch a severe assault on Heart of Darkness. In his essay "An Image of Africa," the famous novelist Chinua Achebe fearlessly states that Conrad "was a bloody racist" on the grounds that his novel regards Africa as "a place of negation ... in comparison with which Europe's own state of spiritual grace will be manifest" (1977: 788; 783). The Africans are never viewed by the European pilgrims as human beings, but phantoms and dirty animals, who are incapable of thinking and speaking; they, as Watts puts it, "are granted speech only to condemn themselves out of their own mouths" (2000: 53). On top of all, they are recurrently described as niggers and brutes, qualities that compelled the racist Kurtz to call in his report to 
'The Society for the Suppression of Savage Customs' for their elimination. It is this demeaning outlook which may have also incited the Kenyan novelist Ngugi Wa Thiong'o to react, in his novel A Grain of Wheat (1967), offensively against Kurtz's disparagement of the Africans by drawing the Kurtzan Thompson, who derides the European imperialists by calling them "the vermin," and claims their extermination (117). However, the Africans' denouncement of Conrad is not postulated by many Western scholars on the ground that Conrad's novel also darkens the image of Europe. According to Terry Eagleton, Conrad's underlying message is that "Western civilization is at base as barbarous as African society..." (1976: 135). Cedric Watts shares Eagleton's opinion in suggesting that both Africans and Europeans are equally evil; if the latter take over the African land and exploit the natives, the former are primitive savages and, more dangerously, they practice dark magic over the alien settlers, a supernatural evil which causes Kurtz's tragic end (2000: see p.54). Watts maintains that the mysterious title of the novel itself may be translated as a symbolic reference to both Africa and Europe as centers of darkness; the novel parallels the diabolic darkness of the African forest and people with the dark reality of the European imperialists, which is stressed not only by Kurtz's inhuman acts but also by referring to the dark history of the Roman and British colonists. Out of this parallelism, Watts concludes that "Britain would once have seemed as savage a wilderness to Roman colonizers as Africa now seems to Europeans" (58-9). C. P. Sarvan has also alleged that Conrad's ironic attitude to colonialism in Africa is more consistent in Heart of Darkness than in any other novel touching upon the problem of racism (see Sarvan 1980: 6-10; rpt. Robert Kimbrough, ed., 280-5). A dispute such as this may drive at concluding that all human beings, with no regard for any boundaries between one nation and another, prove to be racists, although they pretend to be equal brothers most of the time. This may remind us of Marlow's comment that we deceive ourselves by yearning for a 
The Quest for Order: A Comparative Study of J. Conrad's Heart of Darkness and W. Golding's Lord of the Flies

dream (brotherhood) that will never come true.

This problem is also given prominence in Golding's Lord of the Flies. Although there is no critical hint that gives credit to this, Golding's boys, who belong to one nation and civilization, may be signaled as racists. Their racism may be of a different kind, in that it is not based on the boundary of colour, as shown above, but on physical and mental divergences. Ralph's physical appearance as a fair and tall boy, sustained with Piggy's high rationalism, qualifies him to be the leader, a matter which makes the other boy Jack do his best to prove that he is much stronger and more qualified. Giving rise to colour-based racism, he and his exponents change their look into primitive Africans and red Indians. A clash here takes place between civilization and savagery. If the individuals of different nationalities and cultures have reason to be racists, on the account that a nation considers itself much better and higher than another, what about boys of the same country? The English boys' bloody brawling over the matter of leadership is perhaps an irony directed not just towards the English people, but towards humanity in general.

More than colour or any other boundary, power has proved to be the motive of racism in the human world. Actually, history is laden with the examples showing that colonialism is mainly more based on the racist boundary of power than on that of, for example, colour or religion. This fact is more evident in Conrad's novel. JanMohamed reaffirms that "Conrad shows that the transformation from the overt to the covert colonialist aims, depicted by the degeneration of Kurtz, is mediated by the infinite power of the conqueror, by his arrogation of the position of a God among the natives" (1985: 90). Spittles takes a similar stance: "Events in Africa stemmed from material greed and lust for power..." (1992: 75). It is on this ground, Spittles maintains, that "Strong societies often do oppress and exploit weaker ones" (75). If situations were reversed, in one sense, if the Africans 
were more powerful than the Europeans, would the latter think of setting a foot in their land? In this same context, if Golding's protagonists Ralph and Jack, who are English and white, were not rivals over authority would they dissent and engage in any bloody dispute? And if Ralph was as powerful as Jack, would he surrender to him? The answer is a definite 'no.'

Both Conrad and Golding debate at length on the issue of communication in the human world. That is, these authors have a real sensation of man's isolation as he is always kept out of touch with the truth for which he keeps searching. To them, even the truth of certain objects grappled by some men is no more than an illusion. Conrad's protagonist Marlow is affected by the reality of Kurtz, the imperialist Belgian company and the Africans. He goes into the Congo with an idealistic view of the European colonizers, that they are volunteers for helping the desperate Africans, but is stunned by their ferocity. However, he cannot firmly take hold of this truth, which has touched his heart terribly, as he is shown to be mystified by everything's uncertainty: "truth stripped of its cloak of time" he says (Heart of Darkness, 53). It is this feeling which has perhaps stopped him from betraying the Hitler-like Kurtz. Marlow also comes to realize that the Africans are far more desperate than reported, and that they are also more wicked and inhuman. The mystery of these people shakes their image in his mind: "The prehistoric man was cursing us, praying to us, welcoming us - who could tell? We were cut off from the comprehension of our surroundings..." (52). Even Kurtz's truth is not communicated plainly to him. Marlow is not sure if Kurtz's cry of "The horror" means a crimination of his acts, a realization of the meaninglessness of this world, or, as Watts assumes, an involvement in a mystery to which no "resolution is offered" (57). In addition to all this, the truth of the imperialists is claimed to be sexist, particularly by women. Nina Pelikan Straus (1987), Bette London (1990), Johanna M. Smith (1989), Elaine Showalter (1991) and others criticize Conrad for bias to 
The Quest for Order: A Comparative Study of J. Conrad's Heart of Darkness and W. Golding's Lord of the Flies

his sex. Straus, for example, considers the male critics as accessories of Marlow, who "brings truth to men by virtue of his bringing falsehood to women" on the ground that Kurtz's Intended is not named in the novel, nor is she allowed to share with Marlow the truth of her fiancé (1987: 130). But, in fact, it is not only women but also all European ordinary men who are kept 'in the dark' about the truth of their country's colonies in alien lands. It may sound very strange that we cannot understand our truth, yet we may tolerate it when we come to realize, as Marlow puts it, that "life is a greater riddle than some of us think it to be" (Heart of Darkness, 106-7).

With a similar effect, Golding's Lord of the Flies echoes the problem of communication. It may seem that the writer has failed to grapple with the truth in the world of the adults; hence - he has taken the venture of looking for it among the youngsters, but he cannot take hold of it either as both groups of persons show to be the same in inheriting a mysterious nature. Unlike Conrad, Golding does not use various images to philosophize his own scope of the truth, as addressed by his hero Marlow, yet he resembles him in letting the reader get to his view of it beneath certain symbolic events, situations and linguistic codes. In the first place, all the boys are removed from the battlefield at home to an isolated island not for the apparent purpose of sparing their innocent souls, but probably for the purpose of distancing them from the abominable truth of their political regimes. A vindication of this exists in the Iudicrousness of these regimes in trying to convince us that they do care about the young human beings when they pay with the lives of the adults, whom they force into sweeping nuclear wars for the sake of spreading their own dominion over other countries. It is indeed an obvious obfuscation of the truth. There are still many other hints in the novel which underscore the intentional isolation of people from the truth. Sounding very much like Kurtz, Jack distracts Ralph and Piggy aside from the truth of the beast on the island by strangling Simon on his way to tell the boys about the dead man 
with the parachute whom they mistake for the beast, which has no existence but within their hearts. Ralph, like Kurtz too, cries not just for the loss of the boys' innocence but for his ignorance of the truth, namely the evil nature of the boys - an ignorance which costs him to lose two of his best friends, Simon and Piggy, and jeopardize his own life. Symbolically, Piggy is also put off the truth, as he cannot see anything after Jack breaks his glasses, signifying not only sight but also civilization and illumination: "I'Il have to be led like a dog" he ironically says. At the end of the novel, Ralph also voices his grief for misunderstanding his friends "under the black smoke before the burning wreckage of the island," which may be interpreted as a symbol of living in a constant mystery (223).

As for the theme of morality, it is covertly expressed in the recurrent hinting at the follies and sins of humans, which have potentially reduced them to less than animals, to vermin. The question that poses itself is: what is the intention of both Conrad and Golding behind their novels? The downfall of their heroes Marlow and Ralph, who may be their spokesmen, can be a clear signal of their dissatisfaction with and bitter criticism of the immorality of the human actions they closely watch throughout their novels. In other words, one can presume that they search for ordered morality in an almost corrupt world; therefore they can never achieve their goal. Watts avers that Conrad's narrative "is partially about the struggle to maintain a humane morality when that morality no longer seems to bear guaranteed validity" (2000: 59). Similarly, at the end of Golding's narrative the English naval officer is terribly shocked to see the supposedly moral and civilized English boys depraved: "I should have thought that a pack of British boys... would have been able to put up a better show than that..." (Lord of the Flies, 222). Even the little boys come out of the burning island "with the distended bellies of small savages" (222). All these paradigms strongly attest to the perversion of moral values into profligacy; then, how can they be literarily 
The Quest for Order: A Comparative Study of J. Conrad's Heart of Darkness and W. Golding's Lord of the Flies

represented in a clear image?

Consciousness and unconsciousness, two well discerned faculties of the mind, are also argued by both Conrad and Golding to be mixed altogether. All Conrad's characters are observed to live in a state of both consciousness and unconsciousness. The Belgian manager in the Congo shows to have no sensation of the ferocity of the colonizers and the foolishness of the colonized that go around him, yet he is conscious of himself as a living person who cares much about his health. Kurtz's consciousness of the mystery clouding Africa makes him at the end unconscious of even himself, a situation which may motivate him to cry, like Ralph in Lord of the Flies, for mercy, or relief from the horror that strikes him. Marlow also undergoes the same situation. From the beginning to the end of his story, he contends for maintaining his integrity, to be quite conscious of his experiences in the Congo, but he repeatedly admits his unconsciousness of many a great scenes of horror and despair that he watches with his eyes and mind. For instance, the real scenes he observes throughout his journeying along the Congo's coast and into the forests seem unreal: "The earth seemed unearthly" he said (Heart of Darkness, 52). In another scene, he returns to declare that his whole journey is "like a weary pilgrimage amongst hints for nightmares" (18). Out of nightmares, is anyone expected to come up with any feeling other than horror? Similarly, in Lord of the. Flies the boys experience such a loss of mental balance. To mention but one example, Simon, whose sensitivity most often leads him to shut himself away from the boys in certain spots on the island to be in close contact with nature, turns into a phantasmagorical boy. His hallucinated meeting in broad day light with Lord of the Flies makes him unaware of anything around. This aberration tells him to "run off and play with the boys" and that he is the "beast" (158). Simon is confused, as are we, for his consciousness of the pig's head hung on a stick turns into illusion when the head comes to speak in person of the Lord of 
Dr. Ahmed Hussein Khalil

the Flies. We become more bewildered by the conversion of this illusion into truth; it is through the phantom of Lord of the Flies that the writer conveys to us the falsehood of the beast's existence on the island and the reality of its residing in the darkness of man's heart. But one may wonder: how can we depend on a truth that comes from phantasmagoria? Such confusion is mainly brought about by the breaking of the borderline between consciousness and unconsciousness.

The final image of the thematic contradiction, namely the human soul and soullessness, is more intricately set into confusion. Human beings who are supposed to have souls, an essential feature that distinguish them from animals, become soulless or 'hollow men,' as T. S. Eliot, who is greatly indebted to Conrad's Heart of Darkness, puts it. 8 The realization that the Victorian and Modern man is wholly taken by secular ways of living, for which he sacrifices his religious and cultural principles, must have prompted both Conrad and Golding to feel sardonically ironic about his soullessness. There are countless examples of this. Once again, Conrad's hero Marlow, along with all the Belgian agents in the Congo, is unprincipled despite his disposition as a principled man: from the very outset up to the end of his story he is careful not to betray the atrocious company he works for to avoid risking his job, although he repeatedly stresses that he has been grieved and thunderstruck by the desperate life of the colonized Africans. He in this way thinks that he is a man of principle on the account that he keeps his promise of remaining faithful to the company's business, even though it were ugly and inhuman. Moreover, he lies to himself and others, as expounded above, to keep this promise he gave before signing the work contract. But he must be unconscious of the fact that he is thereby unprincipled for two main reasons: in the first place, his refusal to tell the truth helps the company go on accomplishing its dirty business in Africa, which is an immoral thing, and, in the second place, he willfully violates religious principles by lying. This 
The Quest for Order: A Comparative Study of J. Conrad's Heart of Darkness and W. Golding's Lord of the Flies

problem of secularity finds its most obvious exemplification in the character of Kurtz. If Marlow sells his soul for money, Kurtz does for power and fame. But since it is not easy to gain such objectives in a potentially magical and dark world like Africa, Kurtz, like Faustus, sells his soul to the devil. It is this devilish power which enables him to extract amounts of ivory far bigger than those amounts collected by all the pilgrims together. But his deep involvement in that mysteriously devilish world of Africa leads to his "pitiful and appalling" animation and horrible death at the end (Heart of Darkness, 90). Doesn't it sound absurd that a man causes his tragic end with his own hands? The Africans are also embodied as weird sorcerers and black devils; describing one of the African mobs he meets on the road to Kurtz, Marlow says: "I let him run on, this papiermâché Mephistopheles, and it seemed to me that if I tried I could poke my forefinger through him, and would find nothing inside but a little loose dirt..." (37). It is thus hardly surprising to read that these soulless people become no more or less than phantoms. In an ironic attitude to such human beings, Watts comments: "A person who sells his soul does at least have a soul to sell," which implies that the majority are soulless (2000: 47).

Soullessness is also a characteristic feature of most of the boys in Lord of the Flies. Jack's hunger for authority and gratification, which are worldly and trivial matters, entices him to manipulate all the boys (except for Ralph, Piggy and Simon) to abandon their civilized souls and be sadistic savages. This perversion of the children into devils is expressed directly and frequently in the second half of the novel, as referred to so far in this paper, yet it is given more depth through the symbolic title and certain episodes. The titular phrase Lord of the Flies is suggested by Dick as "a translation of Beelzebub, the Greek transliteration of the Hebrew Ba'alevuv, and in Judaism and Christianity denotes the principle of evil personified - the Devil, Satan, Mephistopheles" (1967: 27). The evil nature of humans is morally kept from getting into action by the control of both 
Dr. Ahmed Hussein Khalil

reason and social or cultural restraints; therefore, when such sorts of sway give way to evil, it bursts into awful bestiality. Regardless of variation in the names attributed to such impulse (e. g. "original sin," "Adam's Curse," "the darkness of man's heart," or "The Banality of Evil"), it is seen by 'realists' as the law of nature which "only the saint can surmount it by asceticism" (Dick 1967: 27). It is noteworthy here that Golding's employment of the biblical devil is not literal, nor is it literary (like Mephistopheles and Lucifer in Christopher Marlow's Dr: Faustus or Satan in John Milton's "Paradise Lost" and the Bible that had tried to entice the Christ away from God's right path), but rather a dead pig's head buzzing with flies on a piercing stick. With this new image of evil, the writer attempts to allegorically refer to how nasty man's nature is - an image which recalls the representation of the true evilness of the imperialists in Heart of Darkness to the smelly, rotten bones of the dead in a whitewashed grave. Even the interior darkness of the grave finds its echo in Golding's image. Looking into the mouth of Lord of the Flies, Simon could see only "blackness within, a blackness that spread" (Lord of the Flies, 159). Both writers' irony lies in emphasizing the inevitability of our possessing this darkness. Unlike Conrad, who just repeatedly hints at this ironic fact in his novel, Golding personifies evil in making it tell Simon that it is part of him, but indeed of everybody, that never leaves him as long as he lives; "I'm the reason why it's no go?" it says (158). Therefore, it is foolish of Simon to come to run away from it: "This is ridiculous. You know perfectly well you'll only meet me down there - so don't try to escape!," it menaces him (158). Simon's insistence on telling other boys about the reality of the beast may be behind his tragic end. Such an image of Simon is peerlessly idealistic, in that he risks his life for not communing his soul, as Jack and his followers do, with the devil or evil. But this is not strange, because Simon is depicted as an austere monk, and only monks, as previously mentioned, can expel devils by 'asceticism.' 
The Quest for Order: A Comparative Study of J. Conrad's Heart of Darkness and W. Golding's Lord of the Flies

Finally, the technique of both novels is dexterously fashioned to serve their writers' objective. Each novel is chiefly structured on traditional technical devices such as symbolism, paradox, irony, and circulation, yet these are sufficient for producing extremely complex and mysterious pieces of fiction. Much more important is that these devices are strung together in a genuine way. In other words, apart from their being inseparable, these devices are employed to convey uncommon significances. Most of the episodes and characters as well as settings embodied in the narratives are paradoxical; the images of paradox are for the most part voiced through many-faceted and mysterious symbols, with a piercing underlying irony. To mention but one example, both Conrad and Golding work the most common paradox of light and darkness in new ways that have intriguingly proved to be versatile and opaque. It is bizarrely exciting that the image of light (normally recognized as a symbol of reason, good, civilization etc.) is used by these novelists as a facade of darkness, evil and savagery. But the twisting of symbols here functions perfectly in highlighting the writers' savage irony towards civilization, which is represented by Conrad as the interior darkness of a whitened grave and by Golding as the demolishing fire. The wide-ranging connotations of this image of light and darkness, particularly in Conrad, and its close connection with other elements of the structure is perhaps meant to intensify the complexity and opaqueness of the main idea, namely evil, around which each novel revolves. The over-shadowing dominance of darkness, closely aligned with the perversion of many characters and scenes as well as episodes, from the opening to the close of each novel may symbolically underscore the endlessness of evil and mystery in our world. Such general framing of the narratives seems to conceal the writers' ironic denouncement of the dark (or evil) nature of man, which is behind his fall.

But, it is worth mentioning here that Golding's symbolic action may have certain weak points. His primary occupation 
with oversimplifying his story to impart to us the evil nature of man from a child's perspective may have made him have "difficulty integrating his dialogue with the novel's symbolic design" (Dick 1967: 101). The language of his children is magnificent and convincing, yet it is not "meshed with the author's luxurious descriptions of the island, his careful use of color, and particularly his adult point of view against which the actions of the boys were ultimately measured" (Dick 1967: 101). However, this never means that the plot of Lord of the Flies suffers, because it follows "a construction that is so taut that plot and character become inseparable" (Dick 1967: 101).

From the analytical discussion so far, it can be concluded that Conrad and Golding have failed to find an ordered image of all the natural objects they quested. This is projected in the paradoxical depiction of their novels' settings, characters and themes or ideas. Surprisingly, they impute the reason of disorder in the human society in general to just the dark or evil nature of man. And in an attempt to convince their intellectual audience of their very eccentric reality of man, these two writers have most likely drawn on certain ancient myths and religious rituals as embedded in many Greek dramatic works. However, their vision is debatable, despite its acceptance as realistic by several critics, on the account that it is an extreme deviation from the long-established formula of science, particularly psychology, and the norms of religion.

The Greek myths and religious rituals out of which the Greek drama developed may be detected to have found their way into the fictional world of Conrad and Golding. Their attraction to the mythical world of Greece is most likely based on their strong belief in the ideology and philosophy underlying the vague appearance of this world. Their polarization of people into rational and irrational as well as primitive and civilized may find its roots in Euripides' great drama Bacchus (literally the priestesses of Bacchus, a Greek god of wine). These works most often represent the ancient combat between good and evil 
The Quest for Order: A Comparative Study of J. Conrad's Heart of Darkness and W. Golding's Lord of the Flies

as light and darkness, which may exhibit their essential drawing upon the attitudes of Apollo (god of light or illumination, mostly taken as a symbol of 'mind' or 'reason' on the account that he "represents the civilizing arts - healing, poetry, music, law and order") and Dionysus (god of fertility, wine and drama, who stands for 'passion' or 'heart' or what is "elemental in animal and human nature") (Dick 1967: 29). The polarity of 'mind' and 'heart' is expressed in the Greek play through the unequal rivalry between the rationalist Pentheus and the irrational Dionysus and his 'votaries' (Bacchants) over rejecting the latter's new religion, which results in the horrible death of Pentheus as a 'scapegoat.' In a similar Dionysian scene of hunting rituals, Simon is mistaken for the beast and is tragically killed at the hands of the hunting tribe in Lord of the Flies. The only difference between this scene and its mythical source is that Simon, who is more spiritual than rational, is not a typical counterpart of Pentheus, who is a man of authority for being the king of Thebes, but Ralph is. From the beginning of the novel Ralph is pictured as possessed of physical and mental potential, even though Jack denies it, which helps him, besides possessing the conch (signifying power in the Indian mythology, by which Golding is also affected), to win the election for the leadership of the island community. The alteration is perhaps made for the purpose of maintaining the conflict between heart and mind forever, and not just for the simple reason, as suggested by Dick, of sparing the life of Ralph as being the only boy who becomes alert of the "new found knowledge of" man's evilness (Dick 1967: 31). In fact, priority in this should be given to Simon, as discussed so far, but is not given the chance to reveal it to other boys, nor even to live. As symbolic of the spirit or Christ, Simon is not involved in the struggle between heart and mind upon which the plot of the novel is basically constructed. Such a reversion from rationalism to passionate savagery is echoed in the character of Jack and his tribe in Lord of the Flies as well as Kurtz in Heart of Darkness. Nevertheless, such justification is not intended to let both Conrad and Golding get 
Dr. Ahmed Hussein Khalil

away with their mythical polarity between good and evil or heart and mind. After all, the matter of relying upon myths to prove reality sounds ridiculous. Despite their being elemental in the human history all over the world, myths are publicly known to be imaginative.

Another but much more important reason which goads us to discredit both writers' attitude to man's nature is its shaking of the long-established psychological and religious principles from the roots. We have been brought up to accept that man inherits both good and evil impulses. On the other hand, Conrad and Golding try to falsely prove through their representation of the severe conflict between good and evil powers that man is naturally evil. The ends of their novels signify that good (or light) is outshined by evil (or darkness), and civilization by savage primitivism. It is such continuous catapulting of the human world from a progressive state into retrogression which may be behind their failed quest to get to ordered images of the human objects they have quested in their novels. It must have also dragged them into an abject darkness which dominates the general atmosphere of their novels. Dick's comment on Golding, which seems to apply much to Conrad, may turn to be most accurate: "Golding is torn between conveying a philosophy of evil and writing a realistic novel about Dionysian-Apollonian polarity which poets like Euripides, philosophers like Nietzsche, or novelists like Dostoevski, who in a sense is both, can treat more comfortably" (Dick 1967: 33). 9

Even the two writers' application of some deal of reality to the structure of their novels does not also succeed to take them to their objective, to convince us that they are bound up with reality. If Conrad introduces us to certain realistic settings, whether in Europe or Africa, Golding also takes us to an island to the south of England, with a view to making us feel and live in an air of reality. The way these writers describe their settings and characters as well as events and situations may appear realistic, yet most of it deviates from the truth. If it is hard to 
The Quest for Order: A Comparative Study of J. Conrad's Heart of Darkness and W. Golding's Lord of the Flies

believe the extremely intense darkness (symbolically, evil) which overlaps Marlow's journeying into the Congo state in Conrad's novel, it may become much more difficult to credit the behaviour of the children in Golding's novel. Golding's real success exists in literally recording the way the little children speak; they mostly break the English grammar, which is however a believable feature of the children in their ages. For example, wondering about how they have been brought to the island, Ralph says: "We was attacked" instead of saying: "We were attacked;" and Piggy says: "When we was coming down I looked through one of them windows. I saw the other part of the plane" in lieu of: "When we were coming down I looked through one of its [the plane's] windows..." (Lord of the Flies, 8). Similarly, the eloquent speech of Conrad may go well with his European types of characters, who are intellectual adults; since the African characters are denied speech to achieve a certain goal, we cannot judge their language.

However, a reconsideration of such touch of reality may find it implausible. If the divergence in manner of speaking is to be related to the drastic difference in ages of the characters in the two novels, this is going to make us refute Golding's attempt to convince his readers that his boys are no different from the adults, particularly in conduct. Dick seems to agree where he suggests that "these realistic touches are only external since one hears them as children but sees them as adults" (1967: 33). Finally, Golding seems, like Conrad, to be taken by the comprehensive disorder which surrounds him, so he cannot be systematic in his new but odd attitude to children. The question which requires an urgent answer is: What is the real reason of these two writers' failure to find any order in the human world within two different periods of time? This may be ascribed to personal reasons. Conrad's experience of the unsettlement of his family due to the partitioning of their homeland, Poland, "between Russia, Germany and Austria" and their resentful affiliation with the Russians, and his close watch of the horrid 
Dr. Ahmed Hussein Khalil

ways of living in Africa during his journey to the Congo in the last decade of the nineteenth century, all must have affected his view of the human world (Heart of Darkness, vii-viii). Similarly, Golding is haunted by his own experiences in the Second World War. In termination, if Conrad and Golding's quest for order had ended positively, they would not be convincing, for they themselves did not enjoy any order in their life. This does not mean at all that their ultimately pessimistic view of the human world is accurate, because the dominance of chaos or evil in our world can never be logically taken as an ultimate fact of the absence of order, with all connotations of the word. 
- The Quest for Order: A Comparative Study of J. Conrad's Heart of Darkness and W. Golding's Lord of the Flies 
Dr. Ahmed Hussein Khalil

\section{Notes}

1-To the opposite of those academicians proclaiming that Lord of the Flies is thematically and structurally less interesting than other works of the time, Francis E. Kearns pairs it with Salinger's The Catcher in the Rye in his essay: "Salinger and Golding: Conflict on the Campus," America, CVIII (January $26,1963), 136-39$ on the ground that the two admired young readers for touching upon the problem of their 'alienation' in the modern society. Giving more value to the novel, $R$. C. Townsend calls it "fool's gold" in his essay "Lord of the Flies: Fool's Gold?," Journal of General Education, XVI (July, 1964), 160; Bernard S. Oldsey \& Stanley Weintraub, The Art of William Golding, New York: Harcourt, Brace \& World, 1965. On the moral concerns of the novel, see Kenneth Rexroth, "William Golding," Atlantic, CCXV (May, 1965), 96; John Peter, "The Fables of William Golding," Kenyon Review, XIX (Autumn, 1957), 577-92; Samuel Hynes, William Golding, Columbia Essays on Modern Writers, No. 2, New York \& London, 1964, pp. 5-6; Millar MacLure, "Allegories of Innocence," The Dalhousie Review, XL (Summer, 1960), 1945-56

2-For further information about the imperial history of Britain in Africa see R. C. K. Ensor, England 1870-1914, Oxford: Clarendon Press, 1963; Anthony Wood, Nineteenth Century Britain 1815-1914, London: Longman, 1982; Benita Parry, Conrad and Imperialism, London: Macmillan; Ian Watt, Conrad in the Nineteenth Century, Berkeley: Chatto \& Windus, 1980.

3-On the relation between Golding and Ballantyne, see Carl Niemeyer, "The Coral Island Revisited," in College English, XXII (January, 1961), 241-45. Frank Kermode and Golding admit in their essay "The Meaning of It All," in Books and Bookmen, V (October, 1959), 10, that his Lord of the Flies is 
The Quest for Order: A Comparative Study of J. Conrad's Heart of Darkness and W. Golding's Lord of the Flies

"a realistic view of the Ballantyne situation."

4-The following sources give more details on this point: Robert O. Evans, "Conrad's Underworld," in Modern Fiction Studies, 2, 2 (1956), 56-92; Feder Lillan, "Marlow's descent into hell," in Nineteenth Century Fiction, 9, 4 (1955), 280-92.

5-On the historical and cultural background about the Congo State during the colonial time in the 1890 s as well as Conrad's experiences over there, see Robert Kimbrough (ed.), Joseph Conrad's 'Heart of Darkness,' 3rd edn., New York: Norton, 1988, pp. 78-192; Norman Sherry (ed.), Conrad: The Critical Heritage, London: Routledge \& Kegan Paul, 1973; Bruce Harkness (ed.), Conrad's 'Heart of Darkness' and the Critics, Belmont, CA: Wadsworth, 1960; Harold Bloom (ed.), Joseph Conrad's 'Heart of Darkness,' New York: Chelsea House, 1987; Keith Carabine (ed.), Joseph Conrad: Critical Assessments, 4 vols., Roberts bridge: Helm Information, 1992.

6-In their modernist approach to Lord of the Flies, some scholars conclude that the ordered shape of civilization is a 'mirage', which means deceptive and unattainable. See, for example, these websites which host a number of essays on this matter: www.literatureclassics; www.amazon.co.uk.

7-In his essay "The Economy of Manichean Allegory: The Function of Racial Difference in Colonialist Literature," Abdul R. JanMohamed professes that the Western colonization of other counties was motivated by racism: "the imperialist configures the colonial realm as a confrontation based on differences in race, language, social customs, cultural values, and modes of production" (83). Henry Louis Gates, Jr. (ed.) "RACE," WRITING, AND DIFFERENCE, Chicago: The Univ. of Chicago Press, 1985-6. For further information about the image of Africa in colonialist literature, see Philip D. Curtin, The Image of Africa: British 
Dr. Ahmed Hussein Khalil

Ideas and Action, 1780-1850, Madison: Wis, 1964, p. 9; Dorothy Hammond and Alta Jablow, The Africa that Never was: four Centuries of British Writing about Africa, New York, 1970, pp. 49-113; Edward Said, "Secular Criticism," ed. in The World, the Text, and the Critic, Cambridge, Mass., 1983, pp. 9-53; Edward Said, Orientalism, New York, 1978; Katherine George, "The Civilized West Looks at Primitive Africa, 1400-1800," ed. in Isis 49 (Mar. 1958), pp. 62-72; Winthrop D. Jordon, White over Black: American Attitudes toward the Negro, 1550-1812, Chapel Hill: N. C., 1968, pp. 269-311.

8- On Conrad's theme of the absurdity of man's living without soul, see T. S. Eliot, The Hollow Men, ed. By Jough Dempsey on the web. site: http://poetry.poetryx.com/poems/784/; George Williamson, $A$ Reader's Guide to T. S. Eliot, A Poem by Poem Analysis, Britain: Thames \& Hudson, 1967 (rpt. 1984), pp. 154-62.

9- Golding's appeal to the Greek drama and myths is evidenced by countless scholarly works. For example, see F. Dick, "Lord of the Flies and the Bacchae," in The Classical World, LVII (January, 1964), 145-46; E. L. Epstein's note in Lord of the Flies, New York: Capricorn paperback, 1962, p. 250. Golding himself does not deny this influence; in an interview in 1962, he mentioned: "... if I really had to adopt it, I should name thunderous great names like Euripides, and Sophocles, and perhaps even Herodotus. And I might go so far as to say that $I$ have a profound admiration, illogical as it may sound, for Homer." James Baker, William Golding: A Critical Study, New York, 1965, p. xvii. Also, Golding got familiar with the Dionysian religion through intimately reading E. R. Dodd, Euripides Bacchae, 2nd ed., Oxford, 1960. 
The Quest for Order: A Comparative Study of J. Conrad's Heart of Darkness and IV. Golding's Lord of the Flies

\section{Bibliography}

\section{1-Primary sources:}

Conrad, Joseph (1994; Rpt. 2004), Heart of Darkness, Beirut: York Press.

Golding, William (1954), Lord of the Flies, London: Faber and Faber Limited.

\section{2-Secondary sources:}

Achebe, Chinua (1977) "An image of Africa: racism in Conrad's Heart of Darkness" in Massachusetts Review, 17, 4.

Baker, James (1965) William Golding: A Critical Study, New York.

Bloom, Harold (ed.) (1987) Joseph Conrad's 'Heart of Darkness,' New York: Chelsea House.

Brady, Marion B (Oct., 1962). "Conrad's Whited Sepulcher" in College English 24, 1.

Carabine, Keith (ed.) (1992) Joseph Conrad: Critical Assessments, 4 vols., Robertsbridge: Helm Information.

Crankshaw, Edward (1976), Joseph Conrad: some aspects of the art of the novel, London and Basingstoke: The Macmillan Press LTD.

Curtin, Philip D. (1964) The Image of Africa: British Ideas and Action, 1780-1850, Madison: Wis.

Dick, Bernard F. (1967), William Golding, USA: Twayne Publishers, Inc.

Dick, F. (January, 1964) "Lord of the Flies and the Bacchae," in The Classical World, LVII.

Dowden, Wilfred S. (1970) "I Start with Definite Images" in Joseph Conrad: The Imagined style, Nashville: Vanderbilt 
Dr. Ahmed Hussein Khalil

Univ. Press.

Eagleton, Terry (1976) Criticism and Idleology: A Study in Marxist Literary Theory, London: Verso Servan, C.P.C.

Ensor, R. C. K. (1963) England 1870-1914, Oxford: Clarendon Press.

Epstein, E. L. (1962) Lord of the Flies, New York: Capricorn Paperback.

Evans, Robert O. (1956) "Conrad's Underworld," in Modern Fiction Studies, $2,2$.

Gates, Henry Louis, Jr. (ed.) (1985-6) "RACE," WRITING, AND DIFFERENCE, Chicago: The Univ. of Chicago Press.

George, Katherine (Mar. 1958) "The Civilized West Looks at Primitive Africa, 1400-1800," ed. in Isis 49.

Hammond, Dorothy \& Alta Jablow ( 1970) The Africa that Never was: four Centuries of British Writing about Africa, New York.

Harkness, Bruce (ed.) (1960) Conrad's 'Heart of Darkness' and the Critics Belmont, CA: Wadsworth.

Hyland, Peter (1988) "The Little Woman in the Heart of Darkness" in Conradiana 20, 1.

Hynes, Samuel (1964) William Golding, Columbia Essays on Modern Writers, No. 2, New York \& London.

Islam, Shamsul (1975) KIPLING'S 'LAW': A Study of his Philosophy of Life, The Macmillan Press, 1975.

JanMohamed, Abdul R. (1985) "The Economy of Manichean Allegory: The Function of Racial Difference in Colonialist Literature" in Henry Louis Gates, Jr. (ed.) "RACE," WRITING, AND DIFFERENCE, Chicago: The Univ. of Chicago Press.

Jordon, Winthrop D. (1968) White over Black: American Attitudes toward the Negro, 1550-1812, Chapel Hill: N. C.

Kearns, Francis E. (January 26, 1963) "Salinger and Golding: Conflict on the Campus," America, CVIII.

Kermode, Frank \& William Golding (Oct. 1959) "The Meaning of It All," in Books and Bookmen, V.

Kimbrough, Robert (ed.) (1988) Joseph Conrad's 'Heart of 
The Quest for Order: A Comparative Study of J. Conrad's Heart of Darkness and W. Golding's Lord of the Flies

\section{Darkness,' 3rd edn., New York: Norton.}

Klein Herbert G. (1988) "Charting the Unknown: Conrad, Marlow, and the World of Women" in Conradiana 20, 2.

Lall, Ramji (1992) Lord of the Flies, New Delhi: Aarti Book Centre.

Lillan, Feder (1955) "Marlow's descent into hell," in Nineteenth Century Fiction, 9, 4.

London, Bette (1990) The Appropriated Voice: Narrative Authority in Conrad, Forster and Woolf, Ann Arbor: Univ. of Michigan Press.

Lynn, David H. (1989) "Heart of Darkness: Marlow's Heroic Cry" in The Hero's Tale, Narrators in the Early Modern Novel, London: Macmillan.

MacLure, Millar (Summer, 1960) "Allegories of Innocence," The Dalhousie Review, XL.

Montage, George E. (1971-2) "Marlow Tells the Truth: The Nature of Evil in Heart of Darkness" in Conradiana 20, 3, 2.

Moser, Thomas C. (1957) "The Uncongenial Subject" in Joseph Conrad: Achievement and Decline, Cambridge, Mass.: Harvard Univ. Press.

Murfin, Ross C. (ed.) (1989) Joseph Conrad: Heart of Darkness, A Case Study in Contemporary Criticism, New York: St. Martin's Press.

Niemeyer, Carl (January, 1961) "The Coral Island Revisited," in College English, XXII.

Oldsey, Bernard S. \& Stanley Weintraub (1965) The Art of Willian Golding, New York: Harcourt, Brace \& World.

Parry, Benita (1980) Conrad and Imperialism, London: Macmillan; Ian Watt, Conrad in the Nineteenth Century, Berkeley: Chatto \& Windus.

Peter, John (autumn, 1957) "The Fables of William Golding," Kenyon Review, XIX.

Rexroth, Kenneth (May, 1965) "William Golding," Atlantic, CCXV.

Rosmarin, Adena (1989) "Darkening the Reader: Reader- 
Dr. Ahmed Hussein Khalil

Response Criticism and "Heart of darkness" in Ross C. Murfin (ed.) Joseph Conrad, Heart of Darkness: A Case Study in Contemporary Criticism, New York: St. Martin's Press.

Said, Edward (1978) Orientalism, New York.

Said, Edward (1983) "Secular Criticism," ed. in The World, the Text, and the Critic, Cambridge, Mass.

Sarvan, C. P. (1980) "Racism and the 'Heart of Darkness," International Fiction Review 7. Reprinted Kimbrough, ed., Joseph Conrad's 'Heart of Darkness,' pp. 280-5, qt. in Cedric Watts "Heart of Darkness" in J. H. Stape, ed. (2000), The Cambridge Companion to Joseph Conrad, United Kingdom: Cambridge Univ. Press, pp. 55-6

Sherry, Norman (ed.) (1973) Conrad: The Critical Heritage, London: Routledge \& Kegan Paul.

Showalter, Elaine (1991) Sexual Anarchy, London: Bloomsbury. Smith, Johanna M. (1989) "Too beautiful altogether: patriarchal ideology in "Heart of Darkness" in Ross C. Murfin (ed.) Joseph Conrad: 'Heart of Darkness': A Case Study in Contemporary Criticism, New York: Bedford Books of St. Martin's Press.

Spittles, Brian (1992) Joseph Conrad: Text and Context, London: Macmillan.

Stewart, Garrett ((1980) "Lying as Dying in Heart of Darkness" in PMLA 95.

Straus, Nina Pelikan (1987) "The Exclusion of the Intended from Secret Sharing in Conrad's "Heart of Darkness" in Novel, $20,2$.

Thiong'o, Ngugi Wa (1967-1965) A Grain of Wheat, London: Heinemann.

Townsend, R. C. (July, 1964) "Lord of the Flies: Fool's Gold?," Journal of General Education, XVI.

Watt, Ian (1980) Conrad in the Nineteenth Century, Berkeley: Chatto \& Windus.

Watts, Cedric (200o) "Heart of Darkness" in J. H. Stape (ed.) The Cambridge Companion to Joseph Conrad, United 
The Quest for Order: A Comparative Study of J. Conrad's Heart of Darkness and W. Golding's Lord of the Flies

Kingdom: Cambridge Univ. Press.

White, Robert J. (summer, 1964) "Butterfly and Beast in Lord of the Flies," in Modern Fiction Studies, X.

Williamson, George (1967/ 1984) A Reader's Guide to T. S. Eliot, $A$ Poem by Poem Analysis, Britain: Thames \& Hudson.

Wood, Anthony (1982) Nineteenth Century Britain 1815-1914, London: Longman.

Wright, Walter F. (1966) "Ingress to the Heart of Darkness" in Romance and Tragedy in Joseph Conrad, New York: Russell and Russell.

\section{3-Online material:}

www.literatureclassics

www.amazon.co.uk.

The Victorian web.

http://poetry.poetryx.com/poems/784/ 